\title{
The Macroeconomic Analysis: the Main Results of Estimation of Monetary Indicators on the Materials of Russia, the Countries of the Commonwealth of Independent States (CIS) and North-East Asia
}

\author{
Elena Nikolaevna Vyborova \\ Professor, Doctor of economic sciences, Volgograd, Russia. \\ E-mail: el.nik.vyborova@mail.ru
}

Received: August 10, 2019. Revised: September 16, 2019. Accepted: September 20, 2019.

\begin{abstract}
Purpose - This study is to analyze the monetary indicators and the key macroeconomic indicators and to assess the effectiveness of state regulation on its basis. The analysis of monetary aggregates of Russian Federation, CIS, the countries of leading countries of North-East Asia at the present stage of development.

Research design and methodology - The volume of data on Russia was analyzed from the 1995 to the 2018 . The data from the 1950 to the 2019 were estimated on China. The data from the 1980 to the 2018 were estimated on Japan. On South Korea - since the 1960 to the 2018. On Republic of Belarus - since the 2003 to the 2018. On Tajikistan - from the 2008 to 2017. On Kazakhstan - from the 1994 to the 2018. On Kyrgyzstan - from the 2002 to the 2018. On Armenia - from the 2003 to the 2018.

Results - Hypothesis 1: In Russian Federation, the monetary stock has a stable tendency to grow. The volume of money stock of Russia and the analyzed countries is much determined by external debt, GDP, the export, the import, and the international reserves. Hypothesis 2: The growth of money supply does not always give a positive effect in the development of the country, as well as a significant increase in the amount of money stock does not always lead to negative consequences. The monetary stock should be commensurate with the macroeconomic indicators of the state.
\end{abstract}

Conclusions - The growth of the monetary stock does not always give a positive effect in the development of the country, as well as a significant increase in the amount of monetary stock not always lead to negative consequences.

Keywords: Monetary weight, Monetary base, Regulation by monetary movement

JEL Classifications Code: E41, E6, E58. 


\section{Introduction}

State regulation of the main macroeconomic parameters is based on the regulation of monetary indicators, the international reserves, the foreign trade turnover, its structure. The one of the main indicators of the country's development is GDP (Rao, 1968; Teil, 1970; Teil, 1974; Sarkisyan, 1977). Unjustified growth of money stock can lead neither to increase of liquidity of the state, but to the incommensurable losses as a result of inflation. Disproportionate placement of money stock in the economic operations, the sectors of the economy not only does not lead to GDP growth, but also is a ballast in the development of the state (Ezekeel, 1966; Enger, 1976; Dubrov, 1987). The intensive money stock can be regulated by frequent denominations, as the practice in Republic of Belarus, the history of state money management in Russia shows.

This mechanism does not allow the country to develop normally and maintain a sufficiently high level of wellbeing of the nation for a long time. In this regard, we set the objectives of the research: conducting multi-year monitoring of the main indicators of Russia, CIS countries, the leading countries of North-East Asia; identification of optimal basic economic proportions of macroeconomic indicators; identification of trends in the regulation of macroeconomic parameters and assessment of their consequences. In the framework of this article we will present interim results of monitoring of monetary and the main macroeconomic indicators.

The methods of research used the methods of multidimensional statistics such as the component analysis, the factor analysis, the discriminant analysis, the correlation and regression analysis (Adirim \& Yanov, 1977). The accounting procedures were carried out using the application package Statgraphics (Ayvazyan, 1975; Bernstein, 2018). The importance of parameters of the presented equations was checked by the criterion of Student, Fisher (Demidenko, 1981). The estimation of the autocorrelation was determined by the help of Darbina-Watson statistics (Dovba, 1970; Draper \& Smit,1973; Draper, 1987)

\section{The result of analyses}

The monetary base of Russia in the 2018 mainly has a stable tendency to growth. On average, over the past five years, it has grown by the $9.16 \%$ during this period. At the 01.09 .2018 , it amounted to 16118,6 billion RUB. The dynamics of the monetary base during the 2018 has significant fluctuations. By studying the trend of the monetary base, it can be noted that it is described by polynomial of the second degree (Appendix A: Figure 1, 2):

$$
\mathrm{y}=-111,896-0,243 * \mathrm{t}+0,178 * \mathrm{t}^{2}
$$

The monetary stock of Russia in the 2018 had a tendency to rise, on the average for the five years it increases by the 7,88\% and on 01.09 .2018 , and is 44369,1 billion RUB (Figure 1, Appendix A: Figure 3).

\section{The dynamics of monetary stock of Russia in the 2014-2018, billion RUB}

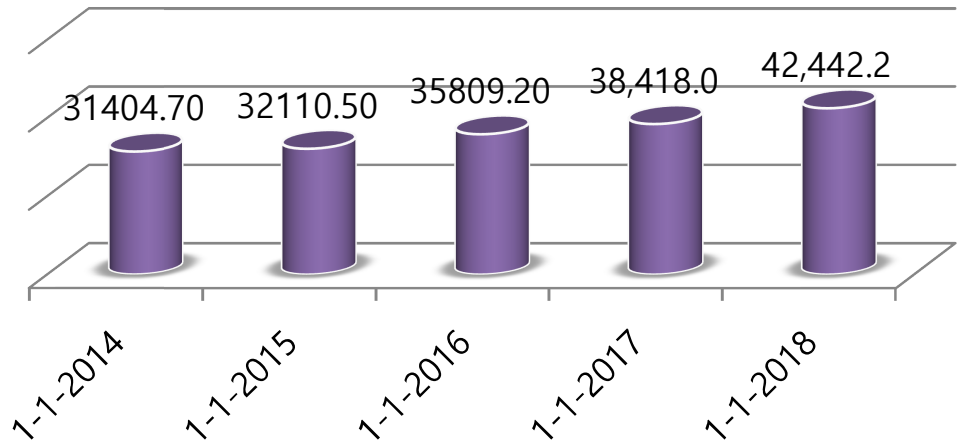

Figure 1: The dynamics of monetary stock of Russia in the 2014-2018. 
The structure of the monetary stock of Russia on the 01.09.2018 can be reflected on the Figure 2.

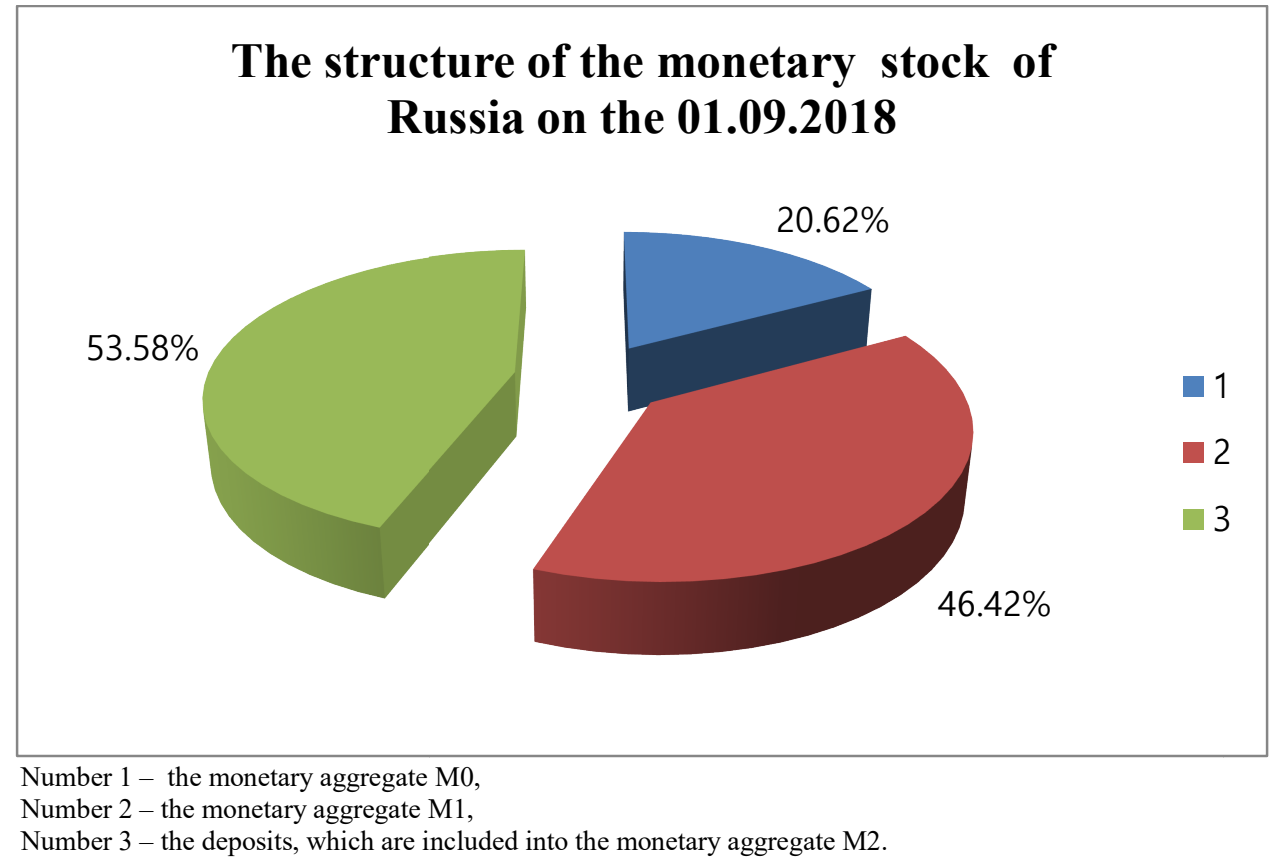

Figure 2: The structure of the monetary stock of Russia (monetary aggregate M2) on the 01.09.2018.

The tendency of development of monetary stock of Russia can be described as follows (Figure 3, Appendix A: Figure 4, 5):

$$
\mathrm{y}=1691,43-81,16 * \mathrm{t}+0,73 * \mathrm{t}^{2}
$$

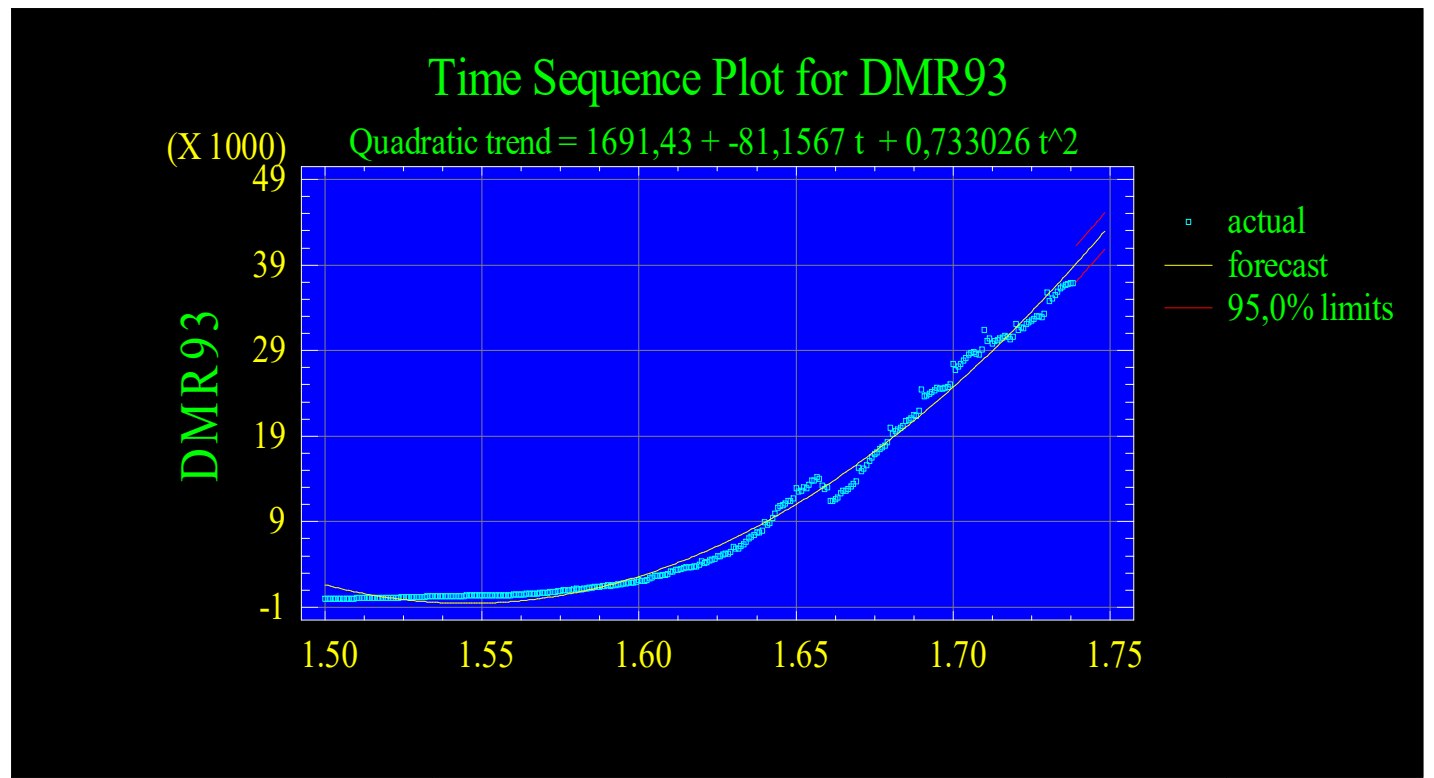

Figure 3: The dynamics of monetary stock of Russia ${ }^{1}$.

\footnotetext{
${ }^{1}$ The data array was investigated with the 1993 г. to 01.09.2018.
} 
The results of component analysis, the factor analysis, the discriminant analysis, the correlation-regression analysis of data since the 2011 showed a high degree of dependence of the monetary stock on the volume of exports and the imports. The monetary stock is determined by the export by the $64 \%$ and the imports by the $62,41 \%$. The form of dependence between the factors is presented as follows:

$$
\mathrm{y}=41646,1-156,2 * \mathrm{X} 1-154,7 * \mathrm{X} 2
$$

where X1 - the export, X2 - the import.

With the increase the exports by the one \$ USA, the monetary stock increases by the 156,2 RUB, with the growth of imports of one \$ USA monetary stock increases by the 154,7 RUB.

The international reserves of Russia on the 01.09.2018 amounted to the 459163 mill. \$ USA. Their dynamics have changed slightly over the past five years (Appendix A: Figure 6, 7,8). The structure of the international reserves of Russia during the 2018 does not change significantly and on the 01.09 .2018 of the largest proportion of foreign currency assets $-80,94 \%$, the monetary gold $-16,9 \%$. The dynamics of international reserves is described by a linear trend of the following type:

$$
\mathrm{y}=330,336+999,707 * \mathrm{t}
$$

Estimating the macroeconomic indicators of Russia, it should be noted, that the GDP of the country in the 20172018 grew by on the average of $2,56 \%$ and in the second quarter of 2018 is 24846,6 billion RUB (Appendix A: Figure 9). The trend of GDP development can be represented by polynomial of the second degree of species (Figure 4):

$$
\mathrm{y}=-274,082+34,38 * \mathrm{t}+2,62 * \mathrm{t}^{2}
$$

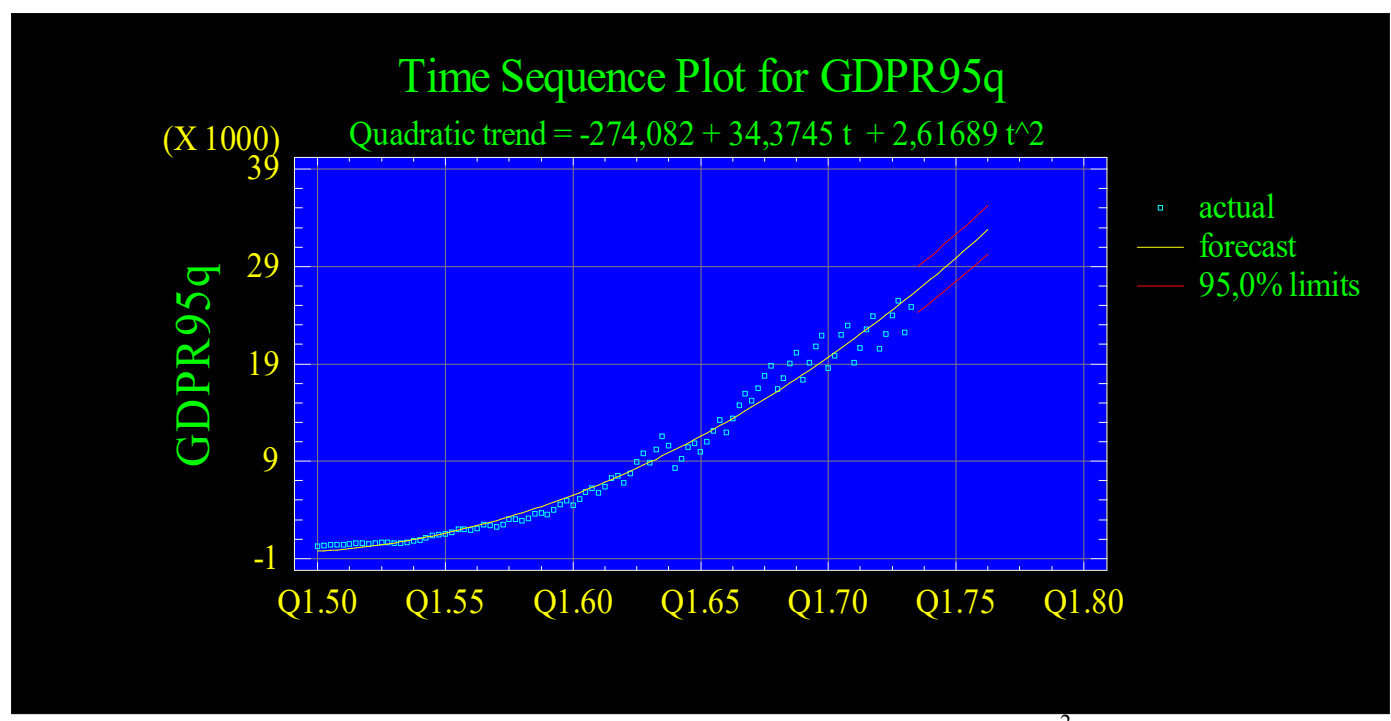

Figure 4: The dynamics of GDP of Russia ${ }^{2}$.

GDP is determined by $68,89 \%$ of the country's external debt. The form of dependence between the factors is presented as follows: ${ }^{3}$ :

$$
\mathrm{y}=-2115+0,034 * X
$$

The amount of domestic debt at the beginning of October 2018 amounted to the 9043 billion RUB. The external debt of Russia in the 2017-2018 has a tendency to decrease and on the 01.09.2018 of the city makes 490697 mill. $\$$ USA (Appendix A: Figure 10). The dynamics of the indicator can be represented by the type model ${ }^{4}$ :

$$
\mathrm{y}=40113,3+23822 * \mathrm{t}-258,32 * \mathrm{t}^{2}
$$

\footnotetext{
${ }^{2}$ The data array was investigated with the 1995 to 01.09 .2018

${ }^{3}$ The data array was investigated in regression analysis with the 2003 to 01.09.2018.

${ }^{4}$ The data array was investigated with the 2003 to 3'Q 2018.
} 
The dynamics of exports and the imports of Russia in the 2017-2018 is not much changed (Appendix A: Figure 11,12). On the 01.09.2018, the export amounted to 34,4 billion. \$ USA, the import $-21,4$ billion $\$$ USA. However, over the past five years there has been a decline in these indicators. The trend of export development can be defined by polynomial of the second degree of type ${ }^{5}$ :

$$
\mathrm{y}=-8,63+0,42 * \mathrm{t}-0,0008 * \mathrm{t}^{2}
$$

The tendency of development of import can be defined as polynomial of the second degree of a kind:

$$
\mathrm{y}=-3,69+0,22 * \mathrm{t}-0,0004 * \mathrm{t}^{2}
$$

There is a high degree of dependence between indicators. The export is determined by import by the $96,04 \%$. With an increase the imports per one \$ USA, the exports grow by the 1,73 \$ USA. The form of the constraint is:

$$
\mathrm{y}=0,16+1,73 * \mathrm{X}
$$

In the 2017, in the foreign trade turnover of Russia the 76,43\% accounted for the trade with Republic of Belarus, the $14,89 \%$ - on the turnover with China, the $8,56 \%$ - on trade with Germany, the $6,76 \%$ - on the turnover with the Netherlands.

\subsection{The assessment of macroeconomic indicators of CIS}

The monetary stock of Republic of Belarus in the 2018 on the average grows by the $0,5 \%$ and on the 01.09 .2018 , it is 40317,79 mill. BYR (Appendix B: Figure 1). During the 2015-2018 years, after the denomination, the increase in the money stock amounted to the $19,25 \%$. The international reserves for the last five years have been growing by the $6,27 \%$ on average and on the 01.09 .2018 is the 7 315,26 million \$ USA (Appendix B: Figure 2). The trend of development of international reserves can be presented in the form of:

$$
\mathrm{y}=693,63+36,51 * \mathrm{t}
$$

The dynamics of the monetary stock of Kazakhstan has no sharp fluctuations and on the 01.08 .2018 is the 19780 billion CZT (Figure 5, Appendix B: Figure 3).

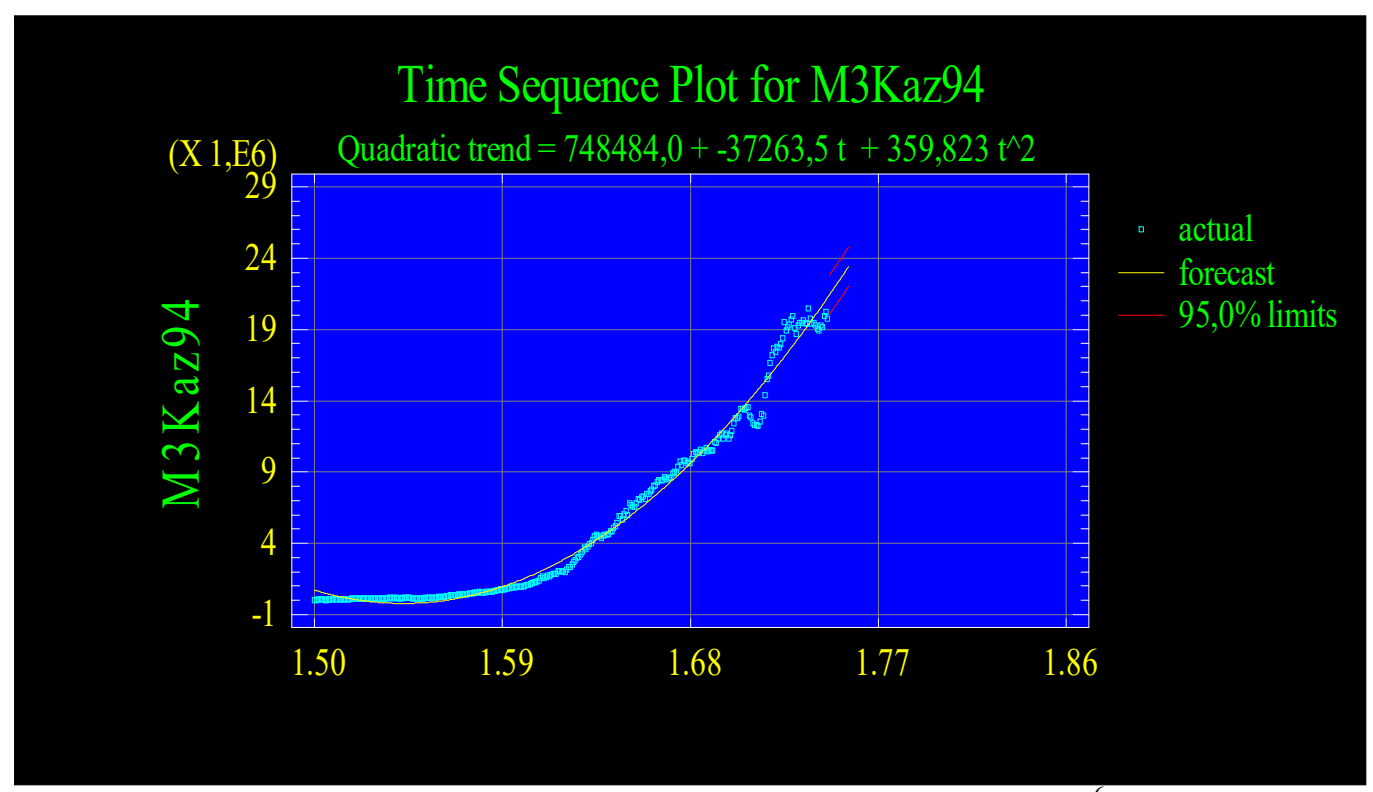

Figure 5: The dynamics of monetary stock of Kazakhstan ${ }^{6}$.

\footnotetext{
${ }^{5}$ The data array was investigated in regression analysis with the 1996 to 01.09 .2018 .

${ }^{6}$ The data array was investigated with the 1994 to 01.08 .2018 .
} 
Over the past five years, it has increased by an average of 13,96\% (Appendix B: Figure 4). The dynamics of monetary aggregates is described as the exponential form of dependence, so polynomial of the second degree. The tendency of development of money mass is described by polynomial of the second degree of type:

$$
\mathrm{y}=74848-37263,5 * \mathrm{t}+359,82 * \mathrm{t}^{2}
$$

The international reserves for the last five years grow by the $6,76 \%$. In the beginning of 2018 have a tendency to decrease and on the 01.09.2018 is the 30028 mill. \$ USA. The dynamics of development is described by linear trend of the kind:

$$
\mathrm{y}=-5189,66+134,28 * t
$$

Estimating the macroeconomic indices of Kazakhstan, we note that external debt in the third quarter of 2018 amounted to the 164422 million \$ USA. A significant share takes a long-term external debt, which tends to decrease. According, to the results of the research of data array from the 2001 on the basis of correlation-regression analysis it is possible to conclude that external debt is determined by export dynamics by the $56,34 \%$, the import dynamics by the $66,7 \%$. The dependency has the form:

$$
\mathrm{y}=6183,06-1,002 * \mathrm{X} 1+14,59 * \mathrm{X} 2,
$$

where X1 - the export, X2 - the import.

Thus, with an increase the exports per one \$ USA the external debt is reduced by the 1,002 \$ USA, with an increase the imports per one \$ USA the external debt increases by the 14,59 \$ USA. The dynamics of external debt development is described by polynomial of the second degree of species (Figure 6):

$$
\mathrm{y}=-13875,6+3969,59 * \mathrm{t}-18,8 * \mathrm{t}^{2}
$$

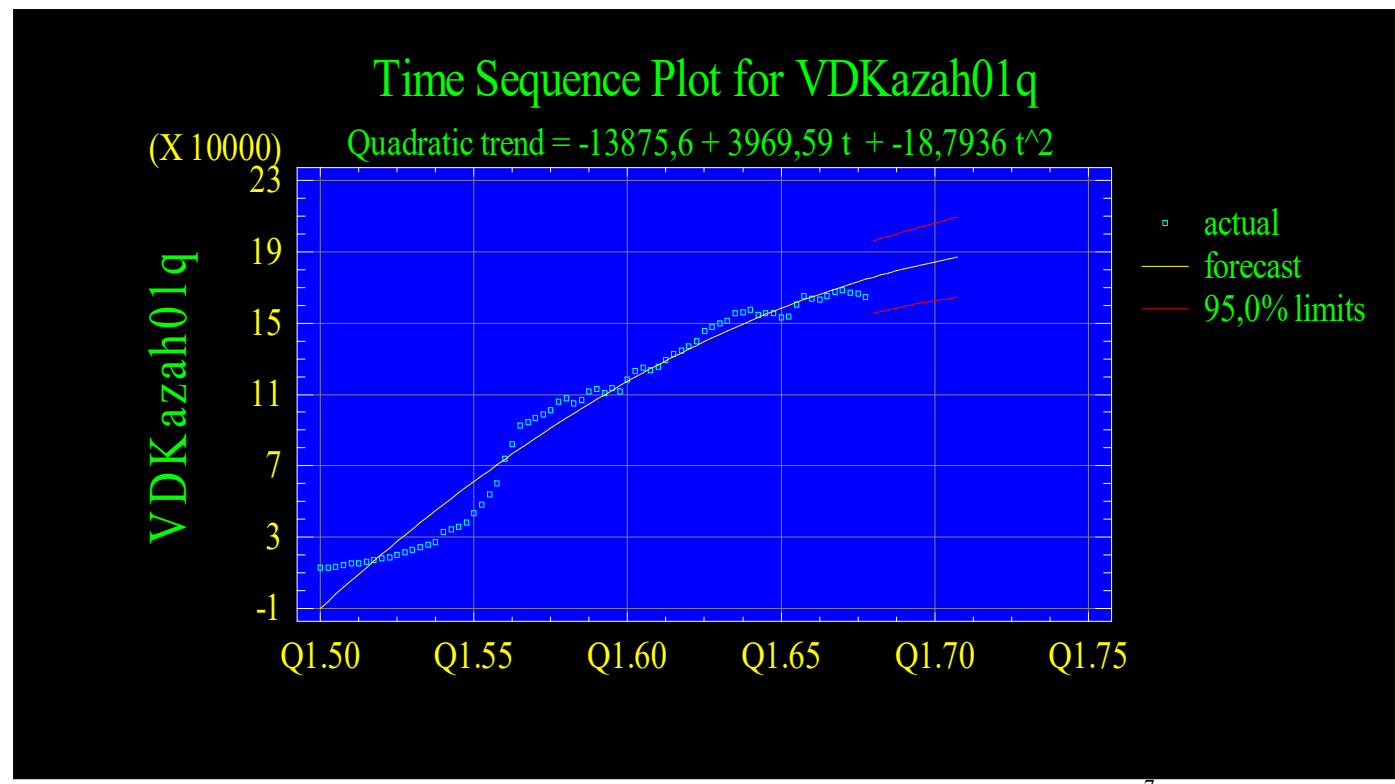

Figure 6: The dynamics of external debt of Kazakhstan

The dynamics of export and the import development is also described by polynomial of the second degree ${ }^{8}$.

\footnotetext{
${ }^{7}$ The data array was investigated with the 2001 to 01.08 .2018 .

${ }^{8}$ The data array was investigated with the 2012 to 01.09 .2018 .
} 
The broad monetary stock of Kyrgyzstan in the last five years on average increases by the $12,61 \%$ and on the 01.09.2018 is 198692,06 million KGS (Appendix B: Figure 7, 8). The tendency of development of the broad monetary stock can be described by polynomial of the second degree of the kind (Figure 7):

$$
\mathrm{y}=84637+789 * \mathrm{t}-7,88 * \mathrm{t}^{2}
$$

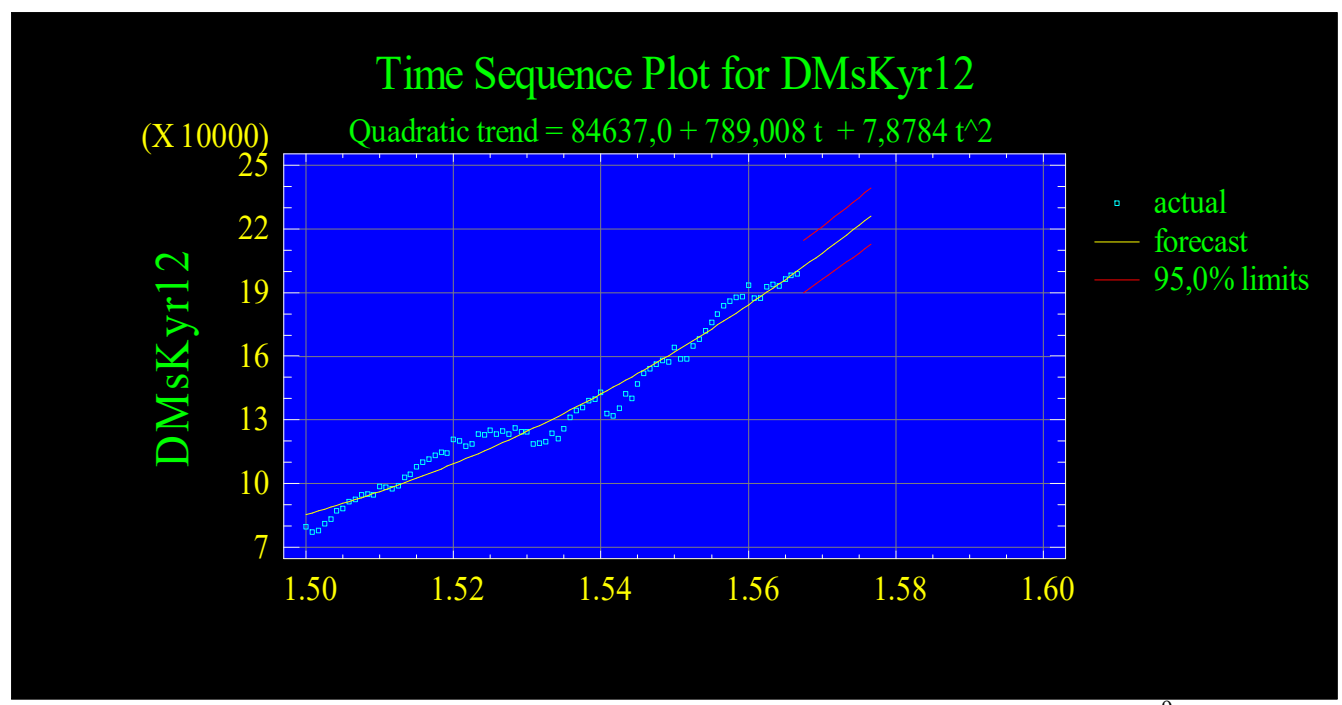

Figure 7: The dynamics of monetary stock of Kyrgyzstan? ${ }^{9}$.

Estimating the macroeconomic indices of Kyrgyzstan, it can be noted that during the last five years there has been no sharp fluctuations in international reserves. A significant reduction in the indicator can be seen in the 2018 on the 01.08 .2018 , they amounted to the 2127,84 million \$ USA. The tendency of development of the international reserves can be described by polynomial of the second degree of type:

$$
\mathrm{y}=-84,14+21,15 * \mathrm{t}-0,05 * \mathrm{t}^{2}
$$

There have been no drastic changes in the dynamics of exports and the imports over the past five years. The trend of export development is presented by the view model:

$$
\mathrm{y}=214,33+4,72 * \mathrm{t}+0,069 * \mathrm{t}^{2}
$$

The trend of the import development is presented by the view model:

$$
\mathrm{y}=491,77-9,69 * \mathrm{t}+0,16 * \mathrm{t}^{2}
$$

The export dynamics is determined by the dynamics of imports by the $39,3 \%$. The form of the indicator dependency is:

$$
\mathrm{y}=24,57+0,33 * X 1
$$

That is, when the import increases by the one \$ USA, the export increases by the $0,33 \$$ USA.

The dynamics of international reserves is also determined by the dynamics of imports by the $23,88 \%$. With an increase in the imports per USD, the international reserves are increasing by the $0,86 \$$ USA. The form of the indicator's dependence is as follows:

$$
\mathrm{y}=1684,33+0,86 * \mathrm{X} 1
$$

Tajikistan's monetary stock has tended to grow over the past five years. On average, it increases by the $20,49 \%$. At the 01.08 .2018 it is 18798 million TJS. The dynamics of monetary stock of Tajikistan is also described by

${ }^{9}$ The data array was investigated with the 2011 to 01.09 .2018 . 
polynomial of the second degree. The tendency of development of monetary stock is presented by model of kind (Figure 8):

$$
\mathrm{y}=2437,8+11,42 * \mathrm{t}+0,9 * \mathrm{t}^{2}
$$

The monetary stock of Armenia has tended to grow over the past five years. On average, it grows by the $14,26 \%$ and on the 01.08.2018 is the 2627292 million AMD. The dynamics of monetary aggregates of Armenia is also described as the exponential form of dependence, so the polynomial of the second degree.

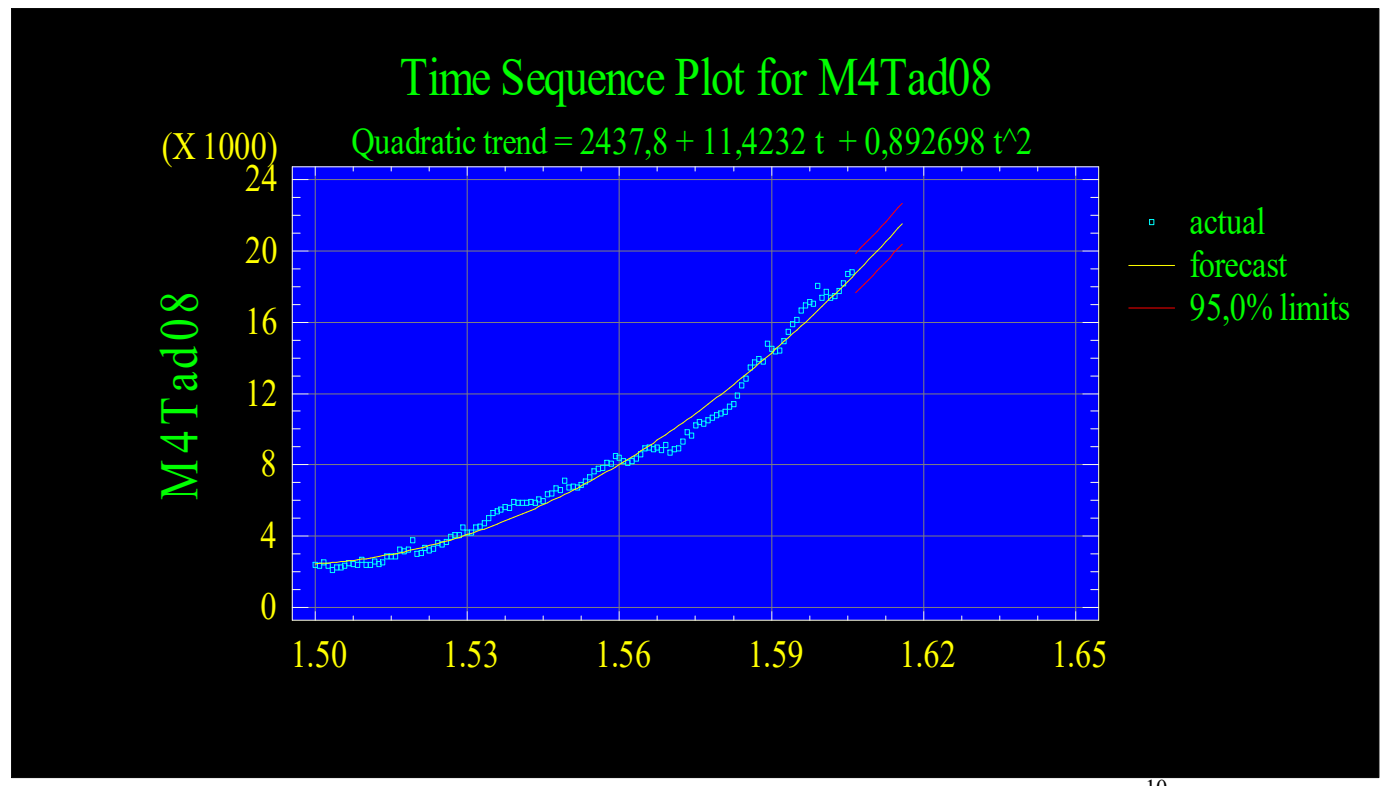

Figure 8: The dynamics of the wide monetary stock of Tajikistan ${ }^{10}$

The tendency of development of the monetary stock is presented by polynomial of the second degree of a kind (Figure 9):

$$
\mathrm{y}=198010+2465,12 * \mathrm{t}+54,04 * \mathrm{t}^{2}
$$

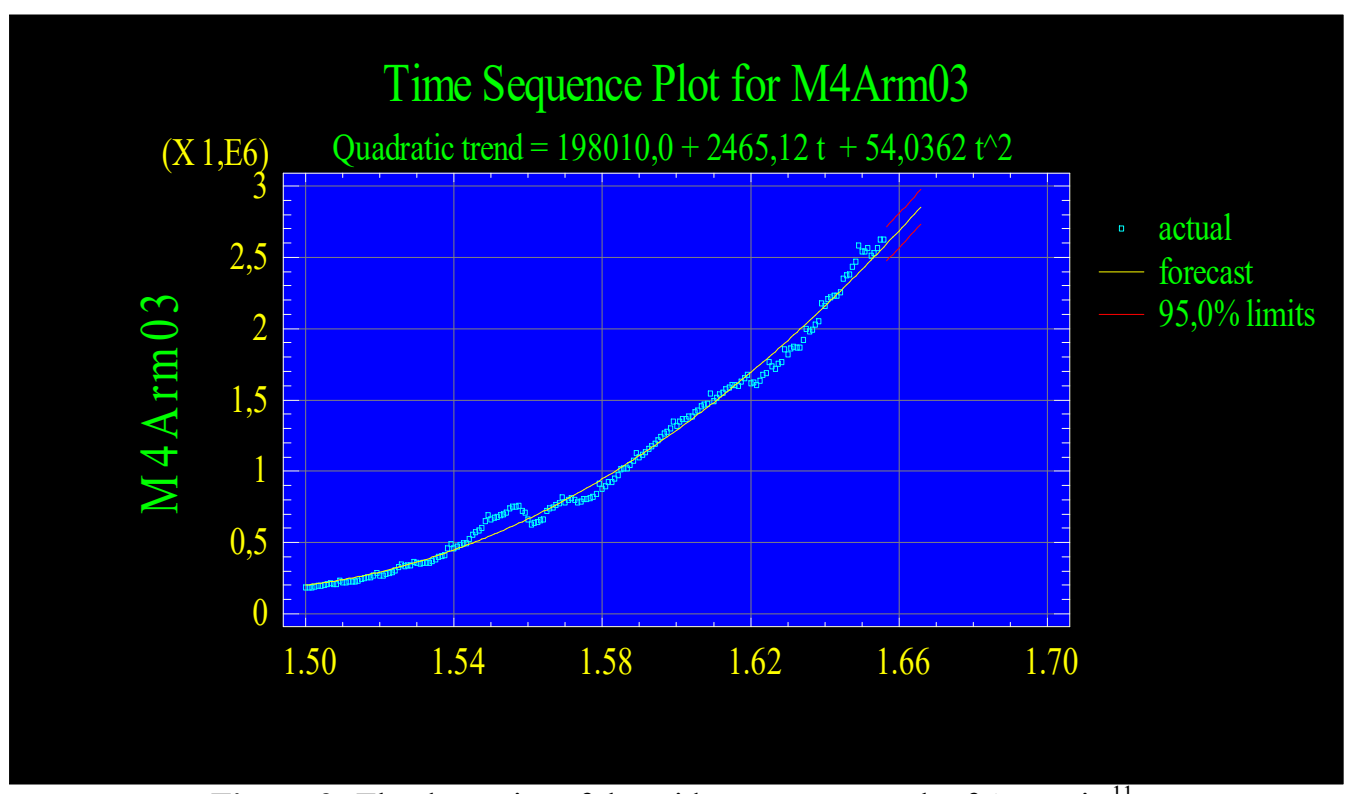

Figure 9: The dynamics of the wide monetary stock of Armenia ${ }^{11}$.

10 The data array was investigated with the 2008 to 01.09 .2018 . 


\subsection{The assessment of macroeconomic indicators of leading countries North-East Asia}

The dynamics of the monetary base of Japan for the last five years increases on the average by the $26,64 \%$ and on the 01.08.2018 of the year is the 498 386,8 billion JPY (Figure 10, Appendix C: Figure 1, 2).

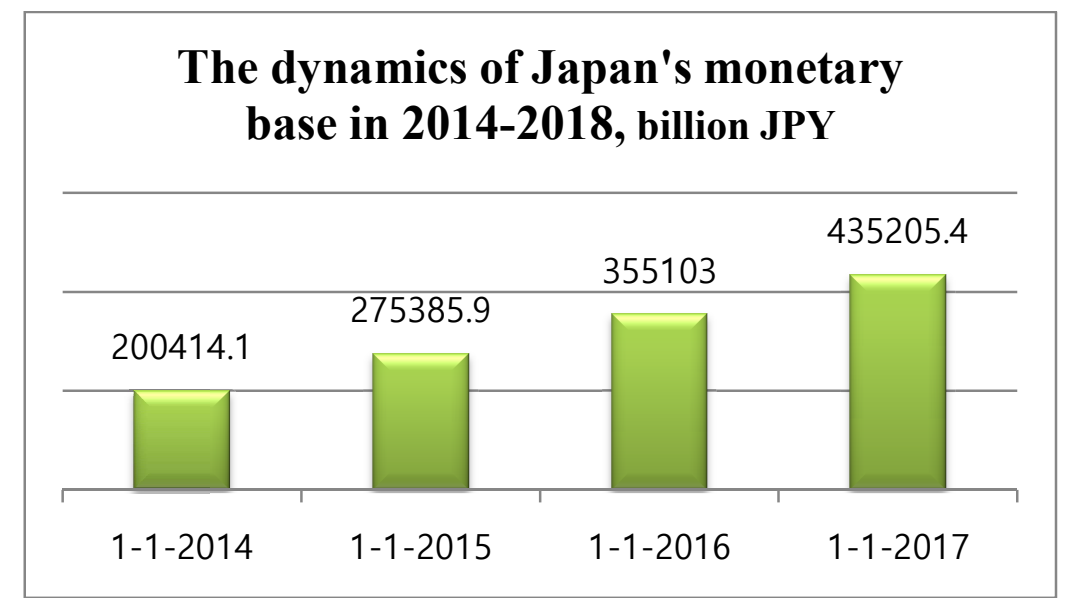

Figure 10: The dynamics of Japan's monetary base in 2014-2018.

The dynamics of the monetary base of Japan can be described by polynomial of the second degree of type:

$$
\mathrm{y}=69807,2-875,9 * \mathrm{t}+3,2 * \mathrm{t}^{2}
$$

China's monetary stock has increased by the $11,26 \%$ in the last five years, on the 01.08 .2018 is 178867 billion CNY (Appendix C: Figure 3,4). The dynamics of the monetary stock can be described by the linear trend of the species (Figure 11):

$$
\mathrm{y}=829072+11938 * \mathrm{t}
$$

The dynamics of the monetary aggregate M0 of China is described by polynomial of the second degree of type:

$$
\mathrm{y}=51009+279,8 * \mathrm{t}-0,12 * \mathrm{t}^{2}
$$

The dynamics of monetary aggregate M1 of China is described by the linear trend of the species:

$$
\mathrm{y}=237067+3731,9 * \mathrm{t}
$$

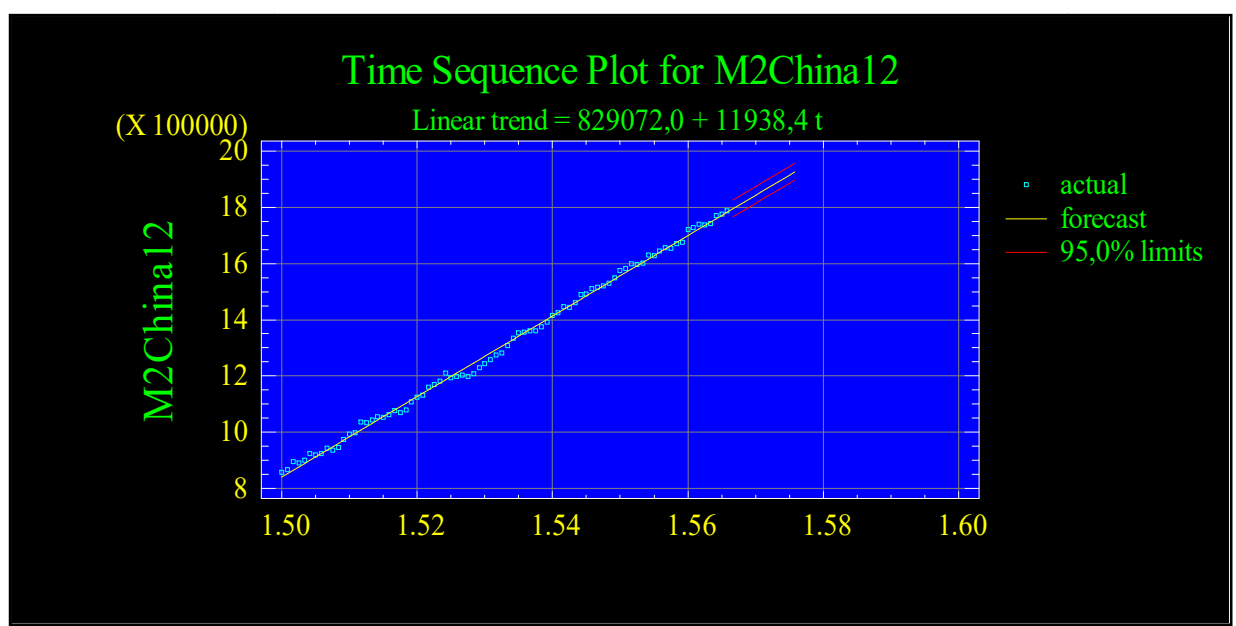

Figure 11: The dynamics of the wide monetary stock of China ${ }^{12}$

\footnotetext{
${ }^{11}$ The data array was investigated with the 2003 to 01.09 .2018 .

12 The data array was investigated with the 2012 to 01.08 .2018 .
} 
The dynamics of China's international reserves have been studied since the 1950 (Appendix C: Figure 5,6). Their tendency is described by polynomial of the second degree of a kind:

$$
\mathrm{y}=698781-90072,5 * \mathrm{t}+1871,53 * \mathrm{t}^{2}
$$

China's external debt is slightly increasing and on the 2017 is the 1710,62 billion $\$$ USA. At the same time its structure in favor of reduction of short-term part and growth of long-term (Appendix C: Figure 7) changes somewhat. China's GDP data have been studied since the 1978, which tends to grow and in the 2016 is the 74412,7 billion CNY (Appendix B: Figure 8,9).

South Korea's monetary base has increased by the $11,52 \%$ over the past five years. The monetary stock grows by the 7,04\% and on the 01.08.2018 is the 2634789,9 billion KRW (Appendix C: Figure 10,11). The study of monetary indicators was carried out on the basis of data from the 1960 to the 2018. The trend of development of monetary indicators can be described by polynomial of the second degree of a kind (Figure 12,13, Appendix C: Figure 12, 13, 14):

The monetary base $-\mathrm{y}=13604,6-215,82 * \mathrm{t}+0,73 * \mathrm{t}^{2}$

The monetary stock (The monetary aggregate M2) -

$$
\mathrm{y}=110752-2721,93 * \mathrm{t}+11,86 * \mathrm{t}^{2}
$$

The monetary aggregate $\mathrm{M} 1-\mathrm{Y}=51050-1001,3 * \mathrm{t}+3,74 * \mathrm{t}^{2}$

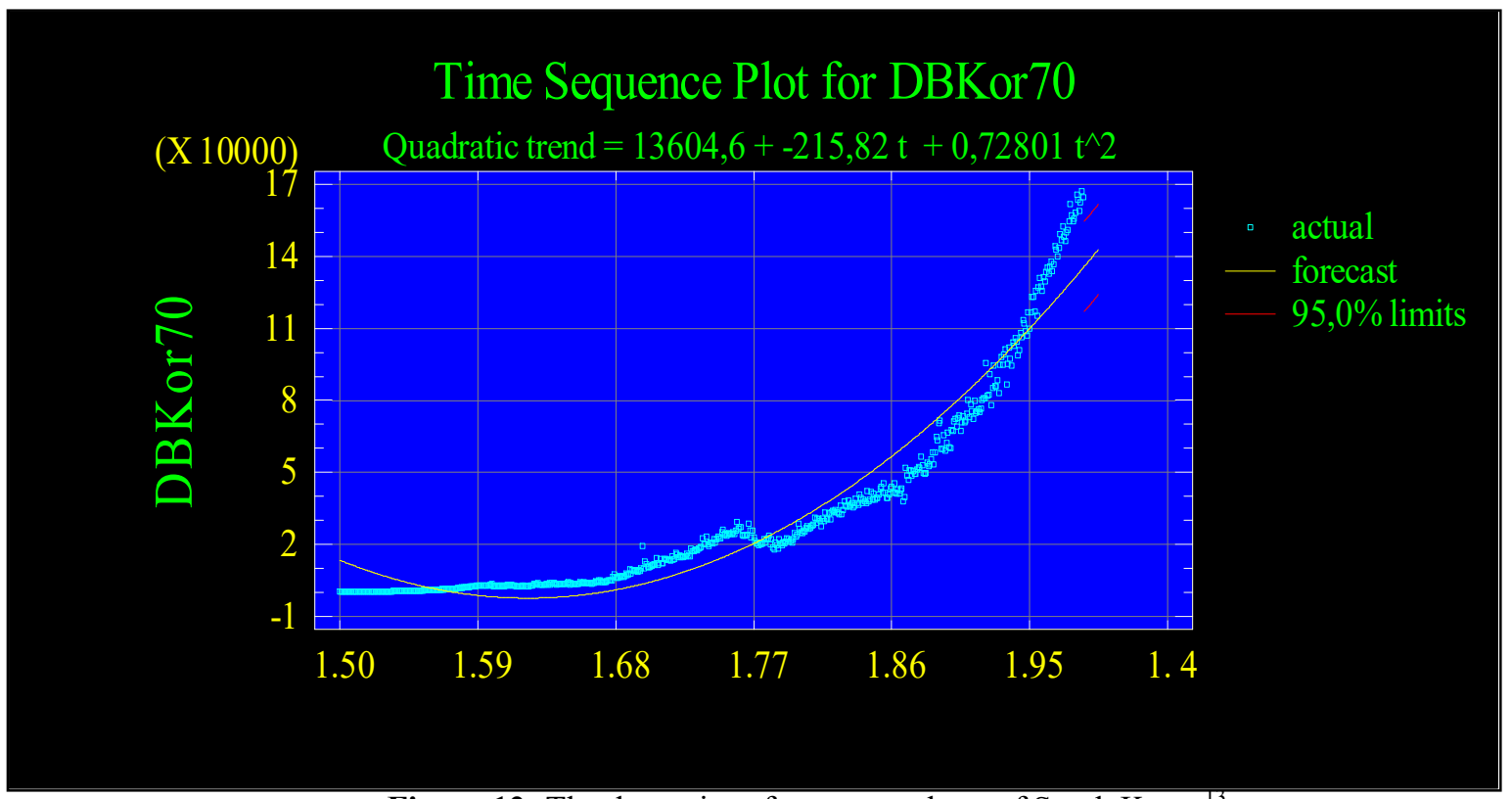

Figure 12: The dynamics of monetary base of South Korea ${ }^{15}$.

13 The data array was investigated with the 1970 to 01.06 .2018 . 


\section{Time Sequence Plot for M2Kor70}

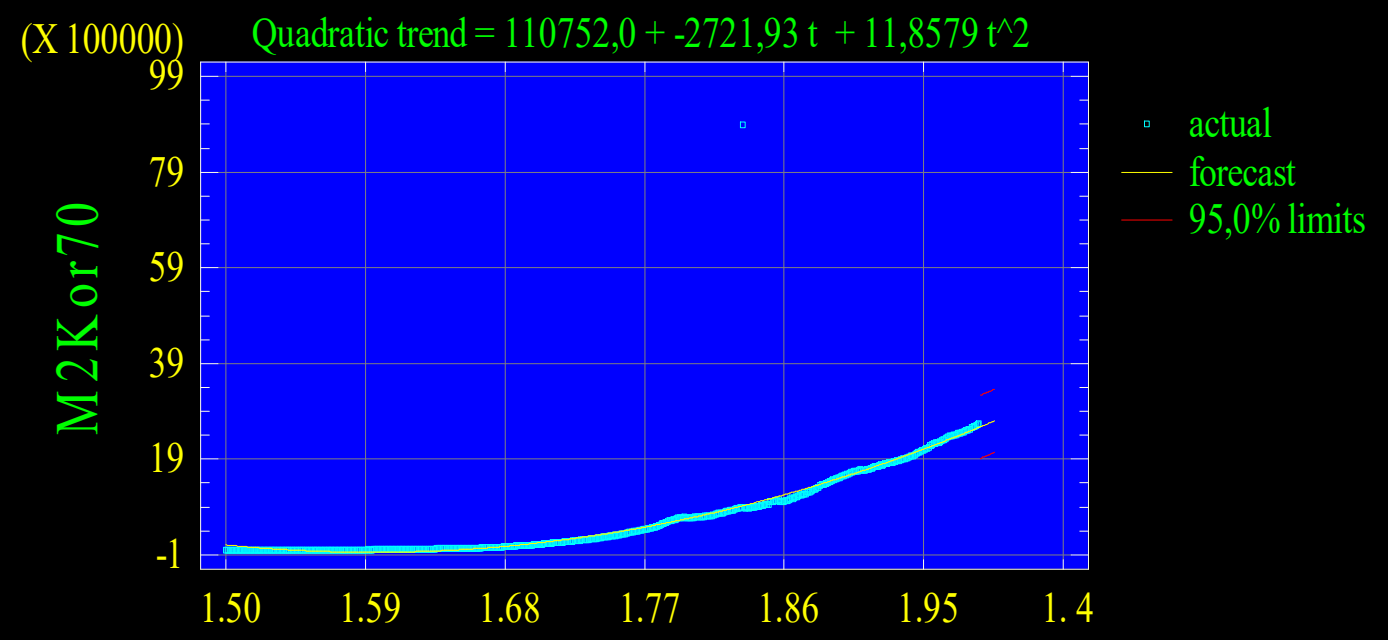

Figure 13: The dynamics of monetary aggregate M2 of South Korea

The international reserves of South Korea have growth trend for five years as well as in the 2018 (Appendix C: Figure 15,16). The trend of development of international reserves can be described by polynomial of the second degree of species (Figure 14):

$$
\mathrm{y}=50536,5-8677,9 * \mathrm{t}+254,1 * \mathrm{t}^{2}
$$

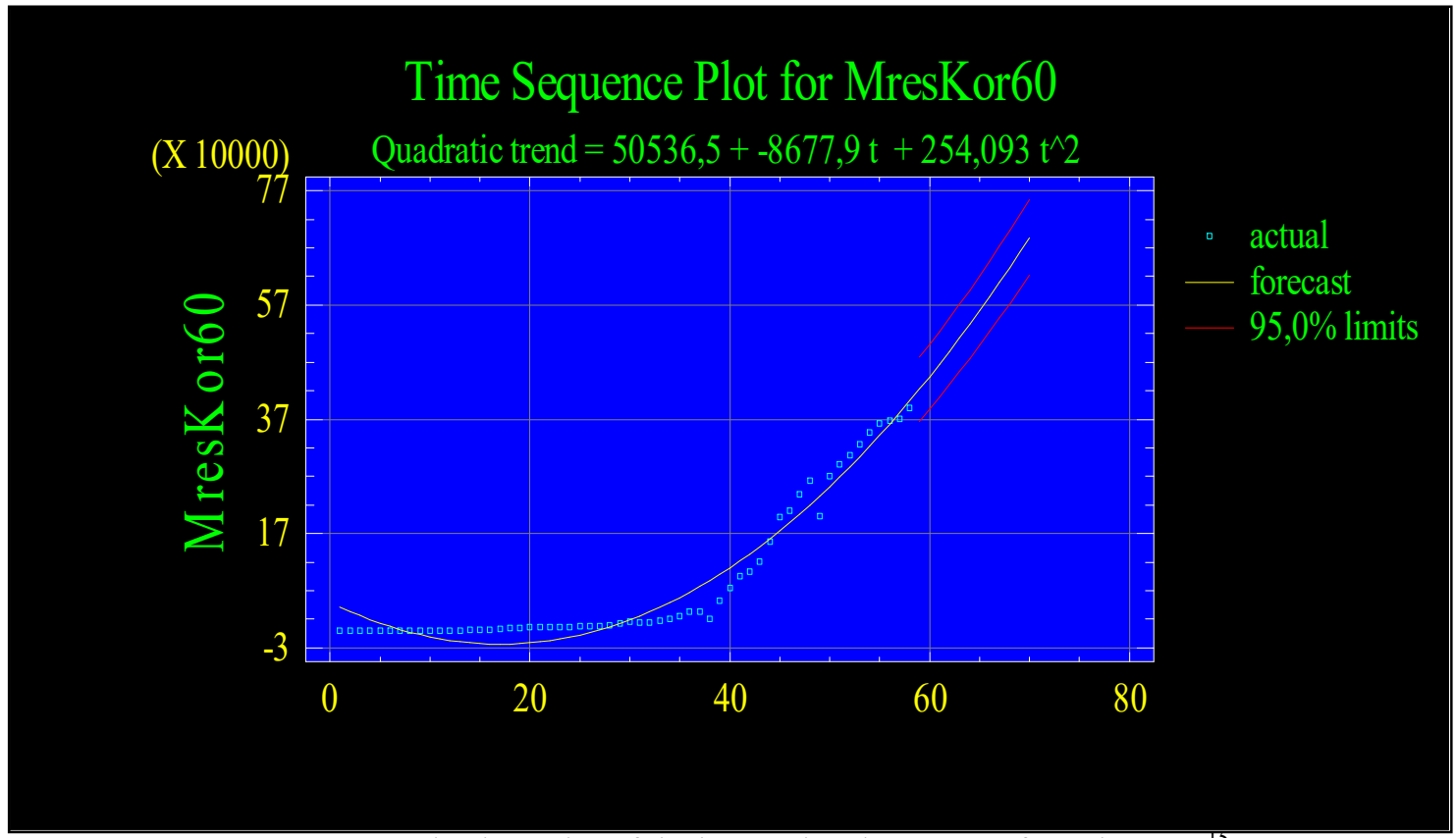

Figure 14: The dynamics of the international reserves of South Korea

\footnotetext{
${ }^{14}$ The data array was investigated with the 1970 to 01.06 .2018 .

15 The data array was investigated with the 1960 to 01.06 .2018$.
} 
The GDP dynamics of South Korea for the five years tends to grow (Appendix C: Figure 17), the tendency of which can be described by polynomial of the second degree of view (Figure 15):

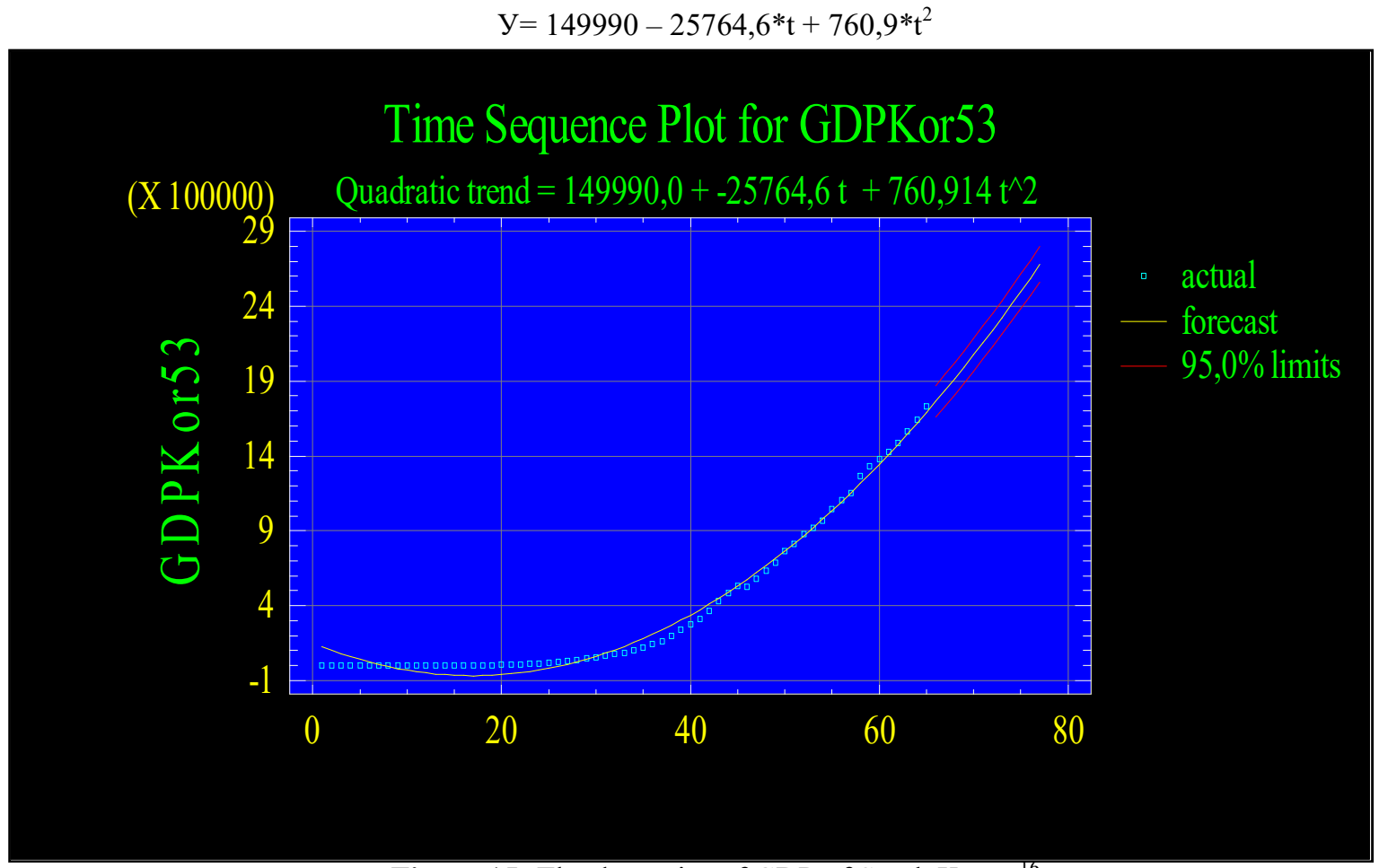

Figure 15: The dynamics of GDP of South Korea

The trend of export and the import development is relatively stable (Appendix C: Figure 18,19). Since the 2014, the foreign trade has seen a decline in turnover, in the 2017, you can see a significant increase. The export in the 2017 compared to the 2016 increases by the $15,81 \%$, the import - by the 17,8\%. Significant growth is tracked by the external debt of South Korea (Appendix C: Figure 20), the trend of which can be described as a polynomial of the second degree and the trend of the species:

$$
\mathrm{y}=81,43-2,6 * t+0,017 * \mathrm{t}^{2}
$$

\section{Conclusion}

There is a positive trend in Russia to reduce the volume of external debt, the imports and GDP growth. The reduction of Russia's international reserves can be considered as a structural tool for managing international indicators. A similar measure of government regulation is observed in China. In the analyzed period in all studied countries it is possible to see a sprout of monetary stock (table 1.2).

Table 1: The monetary and the macroeconomic indicators of Russia, the countries of CIS and North-east Asia

\begin{tabular}{|c|c|c|c|c|}
\hline № & Indicator & Value $^{17}$ & Intensity & The forecast of model \\
\hline & \multicolumn{4}{|c|}{ Russia } \\
\hline 1. & The monetary base & $\begin{array}{l}01.09 .2018 .- \\
16118,6 \text { billion } \\
\text { RUB }\end{array}$ & $\begin{array}{l}\text { The surplus in the } \\
2014-2018 \text { on the } \\
9,16 \%\end{array}$ & $\begin{array}{l}\mathrm{y}=-111,896-0,243 * \mathrm{t}+ \\
0,178 * \mathrm{t}^{2}\end{array}$ \\
\hline
\end{tabular}

\footnotetext{
${ }^{16}$ The data array was investigated with the 1953 to 01.06 .2018 .

${ }^{17}$ Presents official data on the last date.
} 


\begin{tabular}{|c|c|c|c|c|}
\hline 2. & The monetary stock & $\begin{array}{l}\text { 01.09.2018. - } \\
44369,1 \text { billion } \\
\text { RUB }\end{array}$ & $\begin{array}{l}\text { The surplus in the } \\
2014-2018 \text { on the } \\
7,88 \%\end{array}$ & $\begin{array}{l}\mathrm{Y}=1691,43-81,16 * \mathrm{t}+ \\
0,73 * \mathrm{t}^{2}, \\
\mathrm{Y}=18926,2+307,9-81,16 * \mathrm{t} \\
+0,85 * \mathrm{t}^{2}, \\
\mathrm{y}=19672,1+246,63 * \mathrm{t}, \\
\mathrm{y}=41646,1-156,2 * \mathrm{X} 1- \\
154,7 * \mathrm{X} 2 \\
\text { где } \mathrm{X} 1-\text { the export, } \\
\mathrm{X} 2-\text { the import. }\end{array}$ \\
\hline 3. & $\begin{array}{l}\text { The international } \\
\text { reserves }\end{array}$ & $\begin{array}{l}01.09 .2018- \\
459163 \text { mill. } \\
\text { \$ USA }\end{array}$ & $\begin{array}{l}\text { Reduced in the } \\
2014-2018 \text { on the } \\
2,92 \%\end{array}$ & $\mathrm{y}=330,336+999,707 * \mathrm{t}$ \\
\hline 4. & GDP & $\begin{array}{l}\text { 2'Q 2018- } \\
24846,6 \text { billion } \\
\text { RUB }\end{array}$ & $\begin{array}{l}\text { The surplus in the } 1 \text { 'Q } \\
2017-2^{\prime} \mathrm{Q} 2018 \text { on the } \\
2,56 \%\end{array}$ & $\begin{array}{l}\mathrm{Y}=-274,082+34,38 * \mathrm{t}+ \\
2,62 * \mathrm{t}^{2} \\
\mathrm{Y}=-2115+0,034 * \mathrm{X} \\
\text { где } \mathrm{X}-\text { the external debt. }\end{array}$ \\
\hline 5. & The external debt & $\begin{array}{l}01.09 .2018- \\
490697 \text { млн. } \\
\text { \$ США }\end{array}$ & $\begin{array}{l}\text { Reduced in the } \\
2017-3^{\prime} \mathrm{Q} 2018 \text { on the } \\
0,75 \%\end{array}$ & $\begin{array}{l}\mathrm{y}=40113,3+23822 * \mathrm{t}- \\
258,32 * \mathrm{t}^{2}\end{array}$ \\
\hline 6. & The export & $\begin{array}{l}01.09 .2018 .-34,4 \\
\text { billion \$ USA }\end{array}$ & $\begin{array}{l}\text { The surplus in the } \\
2014-2018 \text { on the } \\
0,33 \%\end{array}$ & $\begin{array}{l}\mathrm{Y}=-8,63+0,42 * \mathrm{t}-0,0008 * \mathrm{t}^{2} \\
\mathrm{Y}=0,16+1,73 * \mathrm{X}, \\
\text { где } \mathrm{X} \text { - the import }\end{array}$ \\
\hline 7. & The import & $\begin{array}{l}01.09 .2018 .-21,4 \\
\text { billion \$ USA }\end{array}$ & $\begin{array}{l}\text { Reduced in the } \\
2014-2018 \text { on the } \\
3,39 \%\end{array}$ & $\mathrm{y}=-3,69+0,22 * \mathrm{t}-0,0004 * \mathrm{t}^{2}$ \\
\hline & \multicolumn{4}{|c|}{ CIS } \\
\hline \multirow{2}{*}{8.} & $\begin{array}{l}\text { Republic of Belarus The } \\
\text { monetary stock }\end{array}$ & $\begin{array}{l}01.09 .2018-40 \\
317,79 \\
\text { mill. BYR }\end{array}$ & $\begin{array}{l}\text { The surplus in the } \\
2015-2018 \text { on the } \\
19,25 \%\end{array}$ & \\
\hline & $\begin{array}{l}\text { The international } \\
\text { reserves }\end{array}$ & $\begin{array}{l}01.09 .2018-7 \\
315,26 \text { mill. \$ USA }\end{array}$ & $\begin{array}{l}\text { The surplus in the } \\
2014-2018 \text { on the } \\
6,27 \%\end{array}$ & $\mathrm{y}=693,63+36,51 *_{\mathrm{t}}$ \\
\hline & \multicolumn{4}{|l|}{ Kazakhstan } \\
\hline 9. & The monetary stock & $\begin{array}{l}01.08 .2018 \text { - } \\
19780 \text { billion CZT }\end{array}$ & $\begin{array}{l}\text { The surplus in the } \\
2014-2018 \text { on the } \\
3,96 \%\end{array}$ & $\begin{array}{l}\mathrm{y}=74848-37263,5 * \mathrm{t}+ \\
359,82 * \mathrm{t}^{2}, \\
\text { the monetary aggregate } \mathrm{M} 0- \\
\mathrm{y}=\exp (10,2+0,17 * \mathrm{t})\end{array}$ \\
\hline 10. & $\begin{array}{l}\text { The international } \\
\text { reserves }\end{array}$ & $\begin{array}{l}01.09 .2018-30 \\
028 \text { mill. \$ USA }\end{array}$ & $\begin{array}{l}\text { The surplus in the } \\
2014-2018 \text { on the } \\
6,76 \%\end{array}$ & $\mathrm{y}=-5189,66+134,28 * \mathrm{t}$ \\
\hline 11. & The external debt & $\begin{array}{l}\text { 3'Q } 2018 \text { - } 164422 \\
\text { mill. \$ USA }\end{array}$ & $\begin{array}{l}\text { The surplus in the } \\
2017-3^{\prime} \mathrm{Q} 2018 \text { on the } \\
0,6 \%\end{array}$ & $\begin{array}{l}\mathrm{y}=-13875,6+3969,59 * \mathrm{t}- \\
18,8 * \mathrm{t}^{2}, \\
\mathrm{y}=6183,06-1,002 * \mathrm{X} 1+ \\
14,59 * \mathrm{X} 2 \\
\text { где } \mathrm{X} 1-\text { the export, } \\
\mathrm{X} 2-\text { the import }\end{array}$ \\
\hline 12. & The export & $\begin{array}{l}\text { 2’Q 2018- } \\
15228,9 \text { mill. } \\
\text { \$ USA }\end{array}$ & $\begin{array}{l}\text { The surplus in the } \\
2017-2 \text { 'Q 2018on the } \\
6,94 \%\end{array}$ & $\begin{array}{l}\mathrm{y}=-4221,45+816,96 * \mathrm{t}- \\
7,98 * \mathrm{t}^{2}\end{array}$ \\
\hline 13. & The import & $\begin{array}{l}\text { 2'Q } 2018 \text { г.-- } \\
8 \text { 595,3 mill. } \\
\text { \$ USA }\end{array}$ & $\begin{array}{l}\text { The surplus in the } \\
2017-2^{\prime} \mathrm{Q} 2018 \text { on the } \\
3,2 \%\end{array}$ & $\begin{array}{l}\mathrm{y}=-1338,69+406,85 * \mathrm{t}- \\
3,73 * \mathrm{t}^{2}\end{array}$ \\
\hline
\end{tabular}




\begin{tabular}{|c|c|c|c|c|}
\hline & \multicolumn{4}{|l|}{ Kyrgyzstan } \\
\hline 14. & $\begin{array}{l}\text { The board monetary } \\
\text { stock }\end{array}$ & $\begin{array}{l}01.09 .2018 \text { г. }-198 \\
692,06 \text { mill.KGS }\end{array}$ & $\begin{array}{l}\text { The surplus in the } \\
2014-2018 \text { on the } \\
12,61 \%\end{array}$ & $\mathrm{y}=84637+789 * \mathrm{t}-7,88 * \mathrm{t}^{2}$ \\
\hline 15. & $\begin{array}{l}\text { The international } \\
\text { reserves }\end{array}$ & $\begin{array}{l}01.08 .2018 \text { г. - } \\
2127,84 \text { mill. } \\
\text { \$ USA }\end{array}$ & $\begin{array}{l}\text { The surplus in the } \\
2014-2018 \text { on the } \\
1,06 \%\end{array}$ & $\begin{array}{l}\mathrm{y}=-84,14+21,15 * \mathrm{t}-0,05 * \mathrm{t}^{2} \\
\mathrm{y}=1684,33+0,86 * \mathrm{X} 1 \\
\text { где } \mathrm{X} \text { - the import }\end{array}$ \\
\hline 16. & The export & $\begin{array}{l}\text { 01.07.2018 г. - } \\
\text { 128,4 mill. \$ USA }\end{array}$ & $\begin{array}{l}\text { Reduced in the } \\
2014-2018 \text { on the } \\
9,23 \%\end{array}$ & $\begin{array}{l}\mathrm{y}=214,33+4,72 * \mathrm{t}+0,069 * \mathrm{t}^{2} \\
\mathrm{y}=24,57+0,33 * \mathrm{X} 1 \\
\text { где } \mathrm{X}-\text { the import }\end{array}$ \\
\hline 17. & Импорт & $\begin{array}{l}\text { 01.07.2018 г. - } \\
\text { 399,4 mill. \$ USA }\end{array}$ & $\begin{array}{l}\text { The surplus in the } \\
2014-2018 \text { on the } \\
3,26 \%\end{array}$ & $\mathrm{y}=491,77-9,69 * \mathrm{t}+0,16 * \mathrm{t}^{2}$ \\
\hline 18. & $\begin{array}{l}\text { Tajikistan }{ }^{18} \\
\text { The monetary stock }\end{array}$ & $\begin{array}{l}01.08 .2018 \text { г. - } \\
18798 \text { mill.TJS }\end{array}$ & $\begin{array}{l}\text { The surplus in the } \\
2014-2018 \text { on the } \\
20,49 \%\end{array}$ & $\begin{array}{l}\mathrm{y}=2437,8+11,42 * \mathrm{t}+0,9 * \mathrm{t}^{2} \\
\text { the monetary aggregate } \mathrm{M} 0- \\
\mathrm{y}=1804,86-37,36 * \mathrm{t}+ \\
0,8429 * \mathrm{t}^{2} \\
\text { the monetary aggregate } \mathrm{M} 1- \\
\mathrm{y}=2017,25-34,93 * \mathrm{t}+ \\
0,8919 * \mathrm{t}^{2} \\
\text { the monetary aggregate } \mathrm{M} 2- \\
\mathrm{y}=2148,65-29,1 * \mathrm{t}+0,94 * \mathrm{t}^{2}\end{array}$ \\
\hline 19. & $\begin{array}{l}\text { Armenia }^{19} \\
\text { The monetary stock }\end{array}$ & $\begin{array}{l}01.08 .2018 \text { г. - } \\
2627292 \text { mil. } \\
\text { AMD }\end{array}$ & $\begin{array}{l}\text { The surplus in the } \\
2014-2018 \text { on the } \\
14,26 \%\end{array}$ & $\begin{array}{l}\mathrm{y}=198010+2465,12 * \mathrm{t}+ \\
54,04 * \mathrm{t}^{2} \\
\text { the monetary aggregate } \mathrm{M} 0- \\
\mathrm{y}=99165,7+1785,77 * \mathrm{t} \\
\text { the monetary aggregate } \mathrm{M} 12- \\
\mathrm{y}=\exp (11,83+0,01 * \mathrm{t}) \\
\text { the monetary aggregate } \mathrm{M} 23- \\
\mathrm{y}=\exp (11,84+0,013 * \mathrm{t})\end{array}$ \\
\hline & \multicolumn{4}{|c|}{ The countries of North-East Asia } \\
\hline & \multicolumn{4}{|l|}{ Japan $^{20}$} \\
\hline 20. & The monetary base & $\begin{array}{l}01.08 .2018 \text { г. - } \\
498 \text { 386,8 billion } \\
\text { JPY }\end{array}$ & $\begin{array}{l}\text { The surplus in the } \\
2014-2018 \text { on the } \\
26,64 \%\end{array}$ & $\mathrm{y}=69807,2-875,9 * \mathrm{t}+3,2 * \mathrm{t}^{2}$ \\
\hline & \multicolumn{4}{|l|}{ China } \\
\hline 21. & The monetary stock & $\begin{array}{l}01.08 .2018 \text { г. - } \\
178867 \text { billion } \\
\text { CNY }\end{array}$ & $\begin{array}{l}\text { The surplus in the } \\
2014-2018 \text { on the } \\
11,26 \%\end{array}$ & $\begin{array}{l}\mathrm{y}=829072+11938 * \mathrm{t} \\
\text { the monetary aggregate } \mathrm{M} 0- \\
\mathrm{y}=51009+279,8 * \mathrm{t}-0,12 * \mathrm{t}^{2} \\
\text { the monetary aggregate } \mathrm{M} 1- \\
\mathrm{y}=237067+3731,9 * \mathrm{t}\end{array}$ \\
\hline \multirow[b]{2}{*}{22.} & $\begin{array}{l}\text { The international } \\
\text { reserves }\end{array}$ & $\begin{array}{l}2017 \text { г. }-\quad 3139 \\
949 \text { mill. } \$ \text { USA }\end{array}$ & $\begin{array}{l}\text { Reduced in the } \\
2014-2017 \text { on the } 5 \%\end{array}$ & $\begin{array}{l}\mathrm{y}=698781-90072,5 * \mathrm{t}+ \\
1871,53 * \mathrm{t}^{2}\end{array}$ \\
\hline & The external debt & $\begin{array}{l}2017 \text { г. }-1 \\
710,62 \text { billion } \\
\text { \$ USA }\end{array}$ & $\begin{array}{l}\text { The surplus in the } \\
2014-2017 \text { on the } \\
28,43 \%\end{array}$ & \\
\hline
\end{tabular}

\footnotetext{
${ }^{18}$ The dollar rate on the 01.09.2018 -1\$ USD - 9,4213 TJS.

${ }^{19}$ The dollar rate on the 01.09.2018-1\$ USD - 65,59 AMD.

${ }^{20}$ The dollar rate on the 01.09.2018 - 1\$ USD - 112,32 JPY.
} 


\begin{tabular}{|c|c|c|c|c|}
\hline & South Korea & & & \\
\hline 23. & The monetary base & $\begin{array}{l}01.08 .2018 \text { г. - } \\
164566,5 \text { billion } \\
\text { KRW }\end{array}$ & $\begin{array}{l}\text { The surplus in the } \\
2014-2017 \text { on the } \\
28,43 \%\end{array}$ & $\begin{array}{l}\mathrm{y}=13604,6-215,82 * \mathrm{t}+ \\
0,73 * \mathrm{t}^{2}\end{array}$ \\
\hline 24. & The monetary stock & $\begin{array}{l}01.08 .2018 \text { г. - } \\
2634789,9 \text { billion } \\
\text { KRW }\end{array}$ & $\begin{array}{l}\text { The surplus in the } \\
2014-2017 \text { on the } \\
7,04 \%\end{array}$ & $\begin{array}{l}\mathrm{y}=110752-2721,93 * \mathrm{t}+ \\
11,86 * \mathrm{t}^{2} \\
\text { the monetary aggregate } \mathrm{M} 1- \\
\mathrm{y}=51050-1001,3 * \mathrm{t}+ \\
3,74 * \mathrm{t}^{2}\end{array}$ \\
\hline 25. & $\begin{array}{l}\text { The international } \\
\text { reserves }\end{array}$ & $\begin{array}{l}01.07 .2018 \text { г. - } \\
402447,5 \text { mill. } \\
\text { \$ USA }\end{array}$ & $\begin{array}{l}\text { The surplus in the } \\
2014-2018 \mathrm{jn} \text { the } \\
2,15 \%\end{array}$ & $\begin{array}{l}\mathrm{y}=50536,5-8677,9 * \mathrm{t}+ \\
254,1 * \mathrm{t}^{2}\end{array}$ \\
\hline 26. & GDP & $\begin{array}{l}2017 \text { г.- } \\
1730399 \text { billion } \\
\text { KRW }\end{array}$ & $\begin{array}{l}\text { Reduced in the } \\
2014-2017 \text { on the } 22 \%\end{array}$ & $\begin{array}{l}\mathrm{y}=149990-25764,6 * \mathrm{t}+ \\
760,9 * \mathrm{t}^{2}\end{array}$ \\
\hline \multirow{3}{*}{27.} & The external debt & $\begin{array}{l}\text { 2’Q } 2018-440,5 \\
\text { billion \$ USA }\end{array}$ & $\begin{array}{l}\text { The surplus in the } \\
2014-2017 \text { on the } \\
2,33 \%\end{array}$ & $\begin{array}{l}\mathrm{y}=81,43-2,6 * \mathrm{t}+0,017 * \mathrm{t}^{2} \\
\mathrm{y}=54,37+4,27 * \mathrm{t}\end{array}$ \\
\hline & The export & $\begin{array}{l}2017 \text { г. }-\quad 573,7 \\
\text { billion \$ USA }\end{array}$ & $\begin{array}{l}\text { Reduced in the } \\
2014-2017 \text { in the } \\
24,54 \% \\
\text { The surplus in the } \\
2017 \text { on the } 5,81 \%\end{array}$ & \\
\hline & The import & $\begin{array}{l}2017 \text { г. }-\quad 478,5 \\
\text { billion \$ USA }\end{array}$ & $\begin{array}{l}\text { Reduced in the } \\
2014-2017 \text { on the } \\
26,52 \% \\
\text { The surplus in the } \\
2017 \text { г. On the } 17,8 \%\end{array}$ & \\
\hline
\end{tabular}

The significant increase was in Republic of Belarus, against the background of the denomination held in the 2016, in Kazakhstan, in Tajikistan, in Japan.

The volume of monetary stock in Russia and its growth is rather significant. In the second quarter on the one ruble of GDP $-1,78$ rubles of monetary stock. On the 01.09.2018 the one ruble of external debt accounts for 1,41 rubles of monetary stock and for the one \$ USA - 0,9353 \$ USA of international reserves. These ratios are not entirely critical. In Kazakhstan, in the second quarter of the 2018, the level of foreign debt coverage by the monetary stock and the international reserves is the $33,44 \%$ and the $18,51 \%$ respectively. The increase in the monetary stock in Russia, although significant, compared to the rate of GDP growth, but this figure is the smallest in the group of countries under consideration.

Table 2: The macroeconomic indicators of Russia, the countries of CIS and North-east Asia

\begin{tabular}{|c|c|c|c|c|}
\hline № & Indicator & Period, data & Value & in $\%$ \\
\hline & \multicolumn{3}{|c|}{ Russia $^{21}$} & \\
\hline 1. & $\begin{array}{l}\text { The monetary stock / The } \\
\text { international reserves }\end{array}$ & 01.09 .2018 & $\begin{array}{l}96,64 \mathrm{RUB} / \$ \text { or } 1,51 \\
\text { RUB }\end{array}$ & \\
\hline 2. & $\begin{array}{l}\text { The monetary stock / The external } \\
\text { debt }\end{array}$ & 01.09 .2018 & $\begin{array}{l}90,42 \mathrm{RUB} / \$ \text { or } 1,41 \\
\text { RUB }\end{array}$ & \\
\hline 3. & The monetary stock / The export & 01.09 .2018 & $\begin{array}{l}1289,8 \mathrm{RUB} / \$ \text { or } \\
20,14 \mathrm{RUB}\end{array}$ & \\
\hline 4. & The monetary stock / The import & 01.09 .2018 & $\begin{array}{l}2073,32 \\
\text { RUB/ } \$ \text { or } 32,37 \text { RUB }\end{array}$ & \\
\hline 5 . & The monetary stock / GDP & 2'Q 2018 & $1,78 \mathrm{RUB}$ & \\
\hline
\end{tabular}

\footnotetext{
${ }^{21}$ The dollar rate on the 01.09.2018 - 1\$USD - 64,0447 RUB.
} 


\begin{tabular}{|c|c|c|c|c|}
\hline 6. & $\begin{array}{l}\text { The international reserves / The } \\
\text { external debt }\end{array}$ & 01.09 .2018 & 0,9353 \$ USA & $93,53 \%$ \\
\hline 7. & $\begin{array}{l}\text { The international reserves / The } \\
\text { export }\end{array}$ & 01.09 .2018 & $13,35 \$$ USA & \\
\hline 8. & $\begin{array}{l}\text { The international reserves / The } \\
\text { import }\end{array}$ & 01.09 .2018 & $21,46 \$$ USA & \\
\hline 9. & The international reserves / GDP & 2'Q 2018 & $\begin{array}{l}0,18385 \text { \$ / RUB or } \\
11,78 \mathrm{RUB}\end{array}$ & $18,39 \%$ \\
\hline 10. & The export / The import & 01.09 .2018 & $1,61 \$$ USA & \\
\hline 11. & The export / GDP & 2’Q 2018 & $\begin{array}{l}0,00847 \$ \text { / RUB or } \\
5,42 \text { RUB }\end{array}$ & $0,85 \%$ \\
\hline \multirow[t]{2}{*}{12.} & The import / GDP & 2'Q 2018 & $\begin{array}{l}0,00486 \text { / RUB or } 0,31 \\
\text { RUB }\end{array}$ & $\begin{array}{l}0,49 \% \text { или } \\
31 \%\end{array}$ \\
\hline & \multicolumn{4}{|c|}{ CIS } \\
\hline \multirow[t]{2}{*}{13.} & $\begin{array}{l}\text { Republic of Belarus }{ }^{22} \\
\text { The monetary stock / The } \\
\text { international reserves }\end{array}$ & 01.09 .2018 & $\begin{array}{l}\text { 5,51 RUB/\$ or } 0,1786 \\
\text { RUB }\end{array}$ & $17,86 \%$ \\
\hline & \multicolumn{4}{|l|}{ Kazakhstan ${ }^{23}$} \\
\hline 14. & $\begin{array}{l}\text { The monetary stock / The } \\
\text { international reserves }\end{array}$ & 01.08 .2018 & $\begin{array}{l}0,6483 \mathrm{CZT} / \$ \text { or } \\
0,0018 \mathrm{CZT}\end{array}$ & $\begin{array}{l}64,83 \% \text { или } \\
0,18 \%\end{array}$ \\
\hline 15. & $\begin{array}{l}\text { The monetary stock / The external } \\
\text { debt }\end{array}$ & 2’Q 2018 & $\begin{array}{l}121,52 \mathrm{CZT} / \$ \text { or } \\
0,3344 \mathrm{CZT}\end{array}$ & $33,44 \%$ \\
\hline 16. & The monetary stock / The export & 2’Q 2018 & $\begin{array}{l}1,3 \text { mils. CZT / } \$ \text { or } \\
3,67 \text { thous. } \mathrm{CZT}\end{array}$ & \\
\hline 17. & The monetary stock / The import & 2'Q 2018 & $\begin{array}{l}\text { 2,4 mill. CZT / \$ or } \\
6,45 \text { thous. CZT }\end{array}$ & \\
\hline 18. & $\begin{array}{l}\text { The international reserves / The } \\
\text { external debt }\end{array}$ & 2'Q 2018 & 0,1851 \$ USA & $18,51 \%$ \\
\hline 19. & $\begin{array}{l}\text { The international reserves / The } \\
\text { export }\end{array}$ & 2’Q 2018 & $2,03 \$$ USA & \\
\hline 20. & $\begin{array}{l}\text { The international reserves / The } \\
\text { import }\end{array}$ & 2’Q 2018 & $3,59 \$$ USA & \\
\hline \multirow[t]{2}{*}{21.} & The export / The import & 2’Q 2018 & 1,77 \$ USA & \\
\hline & \multicolumn{4}{|l|}{ Kyrgyzstan $^{24}$} \\
\hline 22. & $\begin{array}{l}\text { The monetary stock / The } \\
\text { international reserves }\end{array}$ & 01.07 .2018 & $90,86 \mathrm{KGS} /$ \$ USA & \\
\hline 23. & The monetary stock / The export & 01.07 .2018 & $\begin{array}{l}1,5 \text { thous. KGS / } \\
\text { \$ USA }\end{array}$ & \\
\hline 24. & The monetary stock / The import & 01.07 .2018 & 491,52 сом / \$USA & \\
\hline 25. & $\begin{array}{l}\text { The international reserves / The } \\
\text { export }\end{array}$ & 01.07 .2018 & 16,83 \$USA & \\
\hline 26. & $\begin{array}{l}\text { The international reserves / The } \\
\text { import }\end{array}$ & 01.07 .2018 & $5,41 \$$ USA & \\
\hline \multirow[t]{3}{*}{27.} & The export / The import & 01.07 .2018 & 0,3215 \$ USA & $32,15 \%$ \\
\hline & \multicolumn{4}{|c|}{ The countries of North-East Asia } \\
\hline & China $^{25}$ & & & \\
\hline 28. & $\begin{array}{l}\text { The monetary stock / The } \\
\text { international reserves }\end{array}$ & 01.01 .2018 & $\begin{array}{l}\text { 5,48 CNY / \$ USA or } \\
8,72 \mathrm{CNY}\end{array}$ & \\
\hline 29. & $\begin{array}{l}\text { The monetary stock / The external } \\
\text { debt }\end{array}$ & 01.01 .2018 & $\begin{array}{l}10,1 \text { thous. CNY / } \\
\text { \$ USA or }\end{array}$ & \\
\hline
\end{tabular}

${ }^{22}$ The dollar rate on the 01.09.2018 - 1\$ USD - 32,6745 BYR.

${ }^{23}$ The dollar rate on the 01.09.2018 - 1\$ USD - 363,43 CZT.

${ }^{24}$ The dollar rate on the 01.09.2018 - 1\$ USD - 68,0447 KGS.

${ }^{25}$ The dollar rate on the 01.01.2018 г. - 1\$ USD - 6,53 CNY. 


\begin{tabular}{|c|c|c|c|c|}
\hline & & & $1540,52 \mathrm{CNY}$ & \\
\hline 30. & $\begin{array}{l}\text { The international reserves / The } \\
\text { external debt }\end{array}$ & 2017 & 1,84 \$ USA & \\
\hline 31. & South Korea $^{26}$ & & & \\
\hline 32. & $\begin{array}{l}\text { The monetary stock / The } \\
\text { international reserves }\end{array}$ & 01.01 .2018 & $\begin{array}{l}6,5 \text { thous.KRW / } \\
\$ \text { USA or } 6,05 \mathrm{KRW}\end{array}$ & \\
\hline 33. & $\begin{array}{l}\text { The monetary stock / The external } \\
\text { debt }\end{array}$ & 01.01 .2018 & $\begin{array}{l}6,1 \text { thous. KRW / } \\
\$ \text { USA or } 5,72 \mathrm{KRW}\end{array}$ & \\
\hline 34. & The monetary stock / The export & 01.01 .2018 & $\begin{array}{l}4,5 \text { thous. KRW / } \\
\$ \text { USA or } 4,18 \text { Won }\end{array}$ & \\
\hline 35. & The monetary stock / The import & 01.01 .2018 & $\begin{array}{l}5,3 \text { thous. KRW / } \\
\$ \text { USA or } 5,01 \mathrm{KRW}\end{array}$ & \\
\hline 36. & The monetary stock / GDP & 01.01 .2018 & $1,48 \mathrm{KRW}$ & \\
\hline 37. & $\begin{array}{l}\text { The international reserves / The } \\
\text { external debt }\end{array}$ & 01.01 .2018 & $0,945 \$$ USA & $94,5 \%$ \\
\hline 38. & $\begin{array}{l}\text { The international reserves / The } \\
\text { export }\end{array}$ & 01.01 .2018 & 0,6998 \$ USA & $69,98 \%$ \\
\hline 39. & $\begin{array}{l}\text { The international reserves / The } \\
\text { import }\end{array}$ & 01.01 .2018 & 0,8271 \$USA & $82,71 \%$ \\
\hline 40. & The international reserves / GDP & 01.01 .2018 & $\begin{array}{l}2,29 \$ \text { USA / KRW or } \\
2,44 \text { thous. KRW }\end{array}$ & \\
\hline 41. & The export / The import & 01.01 .2018 & 1,199 \$ USA & \\
\hline 42. & The export / GDP & 01.01 .2018 & $\begin{array}{l}3,315 \$ \text { USA / KRW or } \\
3,5 \text { thous. KRW }\end{array}$ & \\
\hline 43. & The import / GDP & 01.01 .2018 & $\begin{array}{l}2,765 \$ \text { USA / KRW or } \\
2,95 \text { thous. KRW }\end{array}$ & \\
\hline
\end{tabular}

The greatest increase can be seen in South Korea and Japan. This fact cannot be considered as negative dynamics as there is a significant growth of GDP in South Korea. At the same time, on the one Won of external debt on the 01.01.2018 is the 5,72 Won monetary stock, or the $94,5 \%$ it is covered by international reserves. The one Won of GDP accounts for the 1,48 Won of monetary stock or the 2,44 thousand Won of international reserves. The ratio of export and the import in the country within the permissible proportions is the 1,2 .

The growth of the monetary stock does not always give a positive effect in the development of the country, as well as a significant increase in the amount of monetary stock not always lead to negative consequences (Iberla, 1980; Kruk, 1985; Kondratiev, 1989). The monetary mass should be commensurate with the macroeconomic indicators of the country (Vyborova, 2018). If the growth of monetary stock is observed an increase in the parameters of development of the State, this measure cannot be evaluated as a negative trend of development (Vyborova,2017a, Vyborova, 2017b, Vyborova, 2017c). It is important to monitor the country's external and domestic debt and the foreign trade turnover (Triseyev, 1987; Tikhomirov, 1993)

\footnotetext{
${ }^{26}$ The dollar rate on the $01.01 .2018-1$ S USD - 1066,38 KRW.
} 


\section{Reference}

Adirim, I. G., Yanov, L. A. (1977). The system of regional forecasting models. Moscow, Russia: Paraclete Press.

Ayvazyan, S. A. (1975). The algorithms of multi-dimensional statistical analysis and their application. Moscow, Russia: Moscow University Press.

Bernstein, A. S. (2018). The methods and the models of economic forecasting. Kiev, Russia: Ampopa.

Central Bank of Russia (2019). Retrieved August 1, 2019, from http://www.cbr

Demidenko, E. Z. (1981). The linear and nonlinear regression. Moscow, Russia: Moscow University Press.

Dovba, A. S. (1970). Application of regression models for forecasting economic indicators. Moscow, Russia: Paraclete Press.

Draper, N. (1987). The applied regression analysis. Moscow, Russia: CamoBap.

Draper, N., \& Smit, G. (1973). Applied regression analysis. Moscow, Russia: Cамовар.

Dubrov, A. M. (1985). Application of mathematical methods in economic researches. Moscow, Russia: Paraclete Press.

Dubrov, A. M. (1987). The methodology of statistical modelling and forecasting of socio-economic potential. Moscow, Russia: Moscow University Press

Enger, N. I. (1976). The mathematical-statistical methods of economic forecasting. Moscow, Russia: Izhevsk Press

Ezekeel, M. (1966). The methods of analysis of correlations and regressions of linear and curvilinear. Moscow, Russia: Izhevsk Press

Federal state statistics service (2019). Available at: http://www.gks

Iberla, K. (1980). The Factorial analysis. Moscow, Russia: Moscow University Press

Kondratiev N. (1989). The problems of economic dynamics. Moscow, Russia: PressPass LLC.

Kruk, D. M. (1985). The fundamentals of economic and social forecasting. Moscow, Russia: Camoвap.

Rao, S. R. (1968). The linear statistical methods and their application. Moscow, Russia: Clever-Publishers

Sarkisyan, S. A. (1977). Modeling the prediction object. Moscow, Russia: Молодая гвардия.

Teil, G. (1970). Applied economic forecasting. Moscow, Russia: Молодая гвардия.

Teil, G. (1974). The economic forecasts and decision-making. Moscow, Russia: Русский путь

Tikhomirov, N. P. (1993). The methods of socio-economic forecasting. Moscow, Russia: Ampopa

Triseyev, Y. P. (1987). The long-term forecasting of economic processes. Kiev, Russia: Amфopa.

Vyborova, E. N. (2017a). The assessment of the monetary market of Russia at the present stage of development. East Asian journal of business economics, 5(1), 33-49.

Vyborova, E. N. (2017b). The evaluation of main monetary indicators of Russia and the leading countries of NorthEast Asia. China. Journal of Chinese economics, 5(2), 1-15.

Vyborova, E. N. (2017c). The evaluation of major macroeconomic indicators in Russia and the leading countriespartners. East Asian journal of business economics, 5(3), 1-32.

Vyborova, E. N. (2018). The express-assessment of main monetary indicators of Russia and the countries of CIS. East Asian journal of business economics, 6(1), 1-30. 


\section{Appendix A}

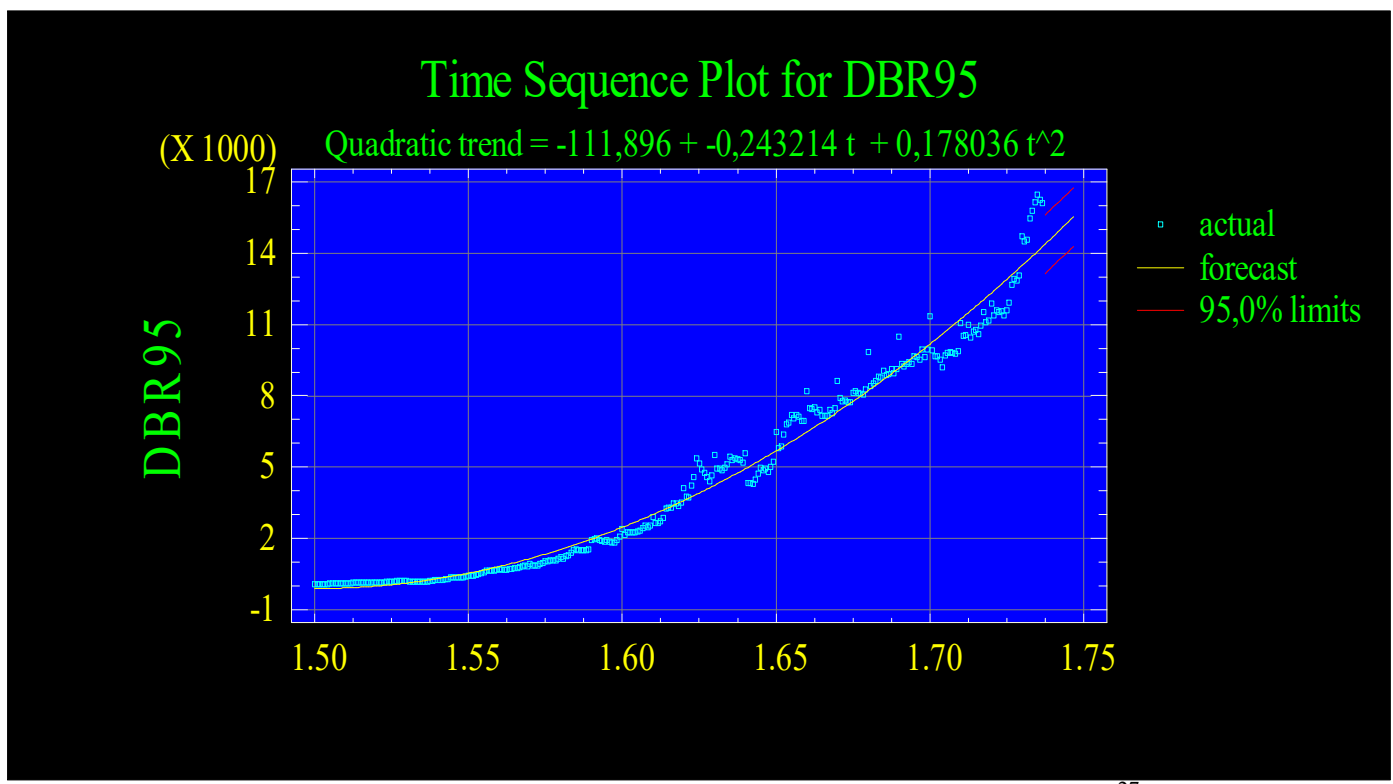

Figure 1: The dynamics of monetary base of Russia ${ }^{27}$.

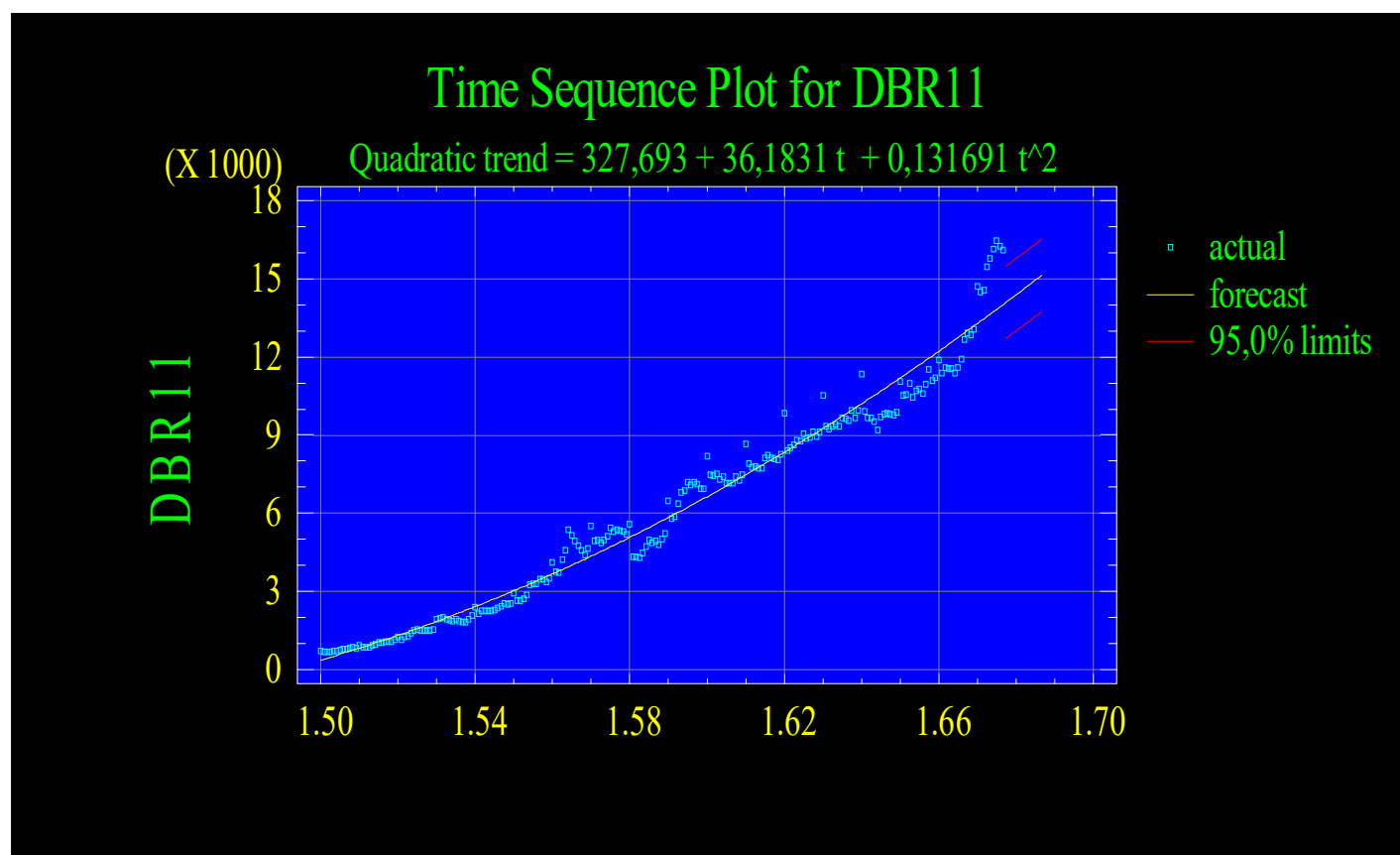

Figure 2: The dynamics of monetary base of Russia ${ }^{28}$.

\footnotetext{
${ }^{27}$ The data array was investigated with the 1995 to 01.09 .2018 .
}

${ }^{28}$ The data array was investigated with the 2011 to 01.09 .2018 . 


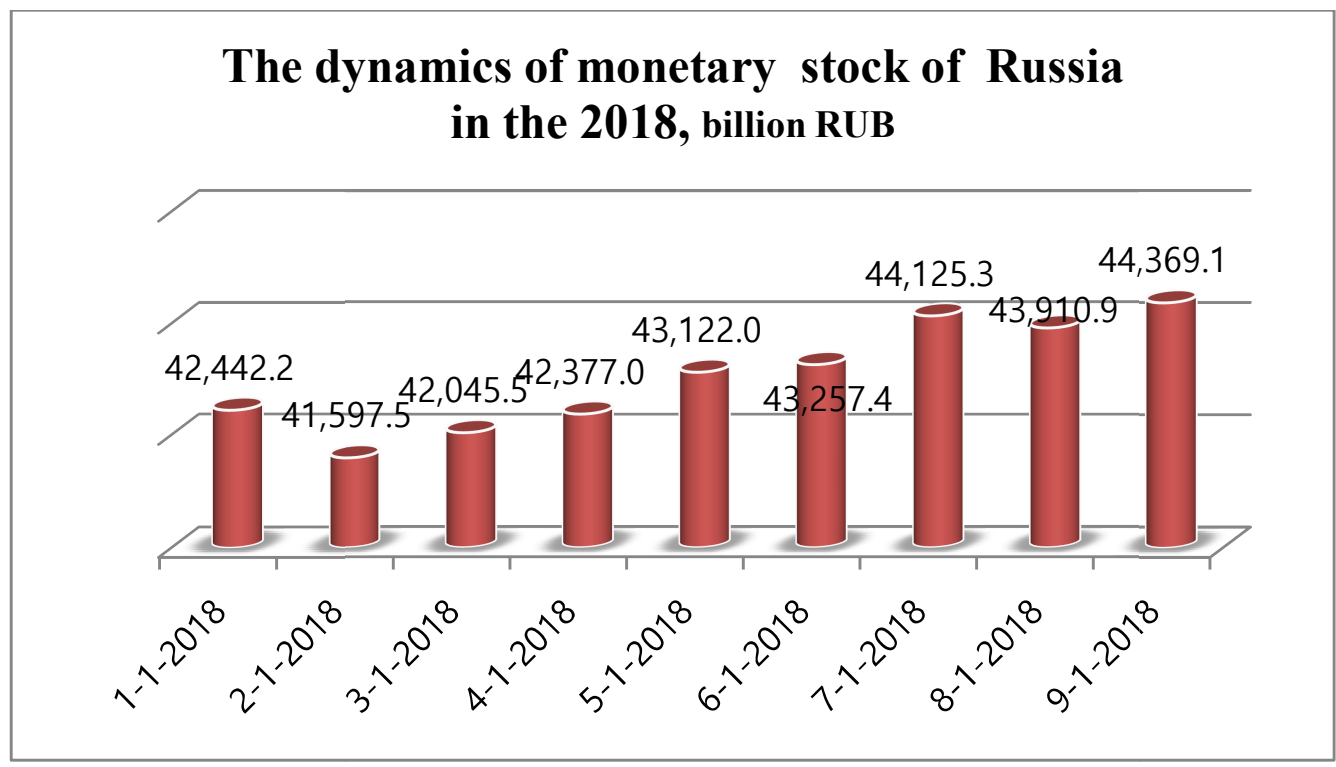

Figure 3: The dynamics of monetary stock of Russia in the 2018.

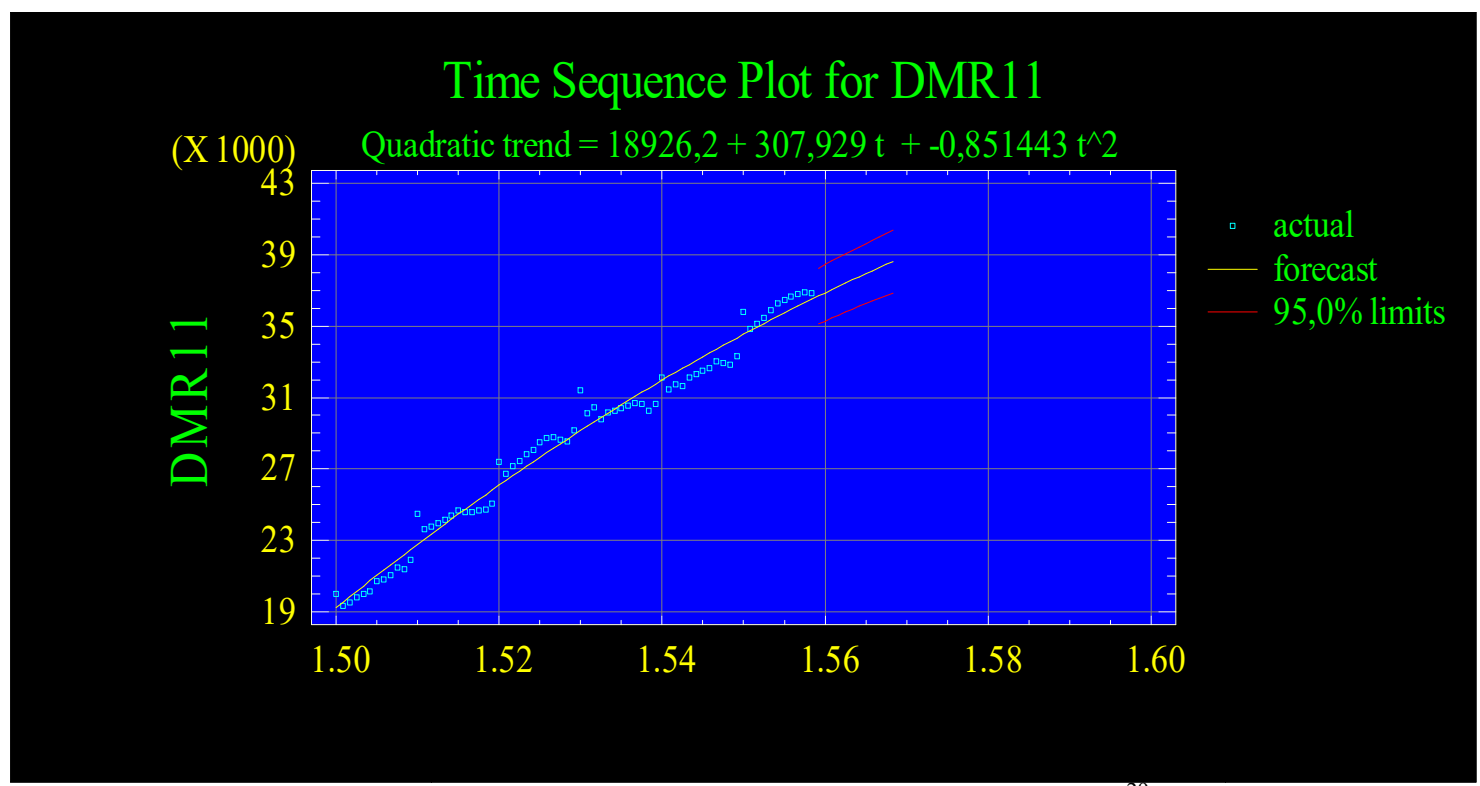

Figure 4: The dynamics of monetary stock of Russia ${ }^{29}$.

\footnotetext{
${ }^{29}$ The data array was investigated with the 2011 to 01.09 .2018 .
} 


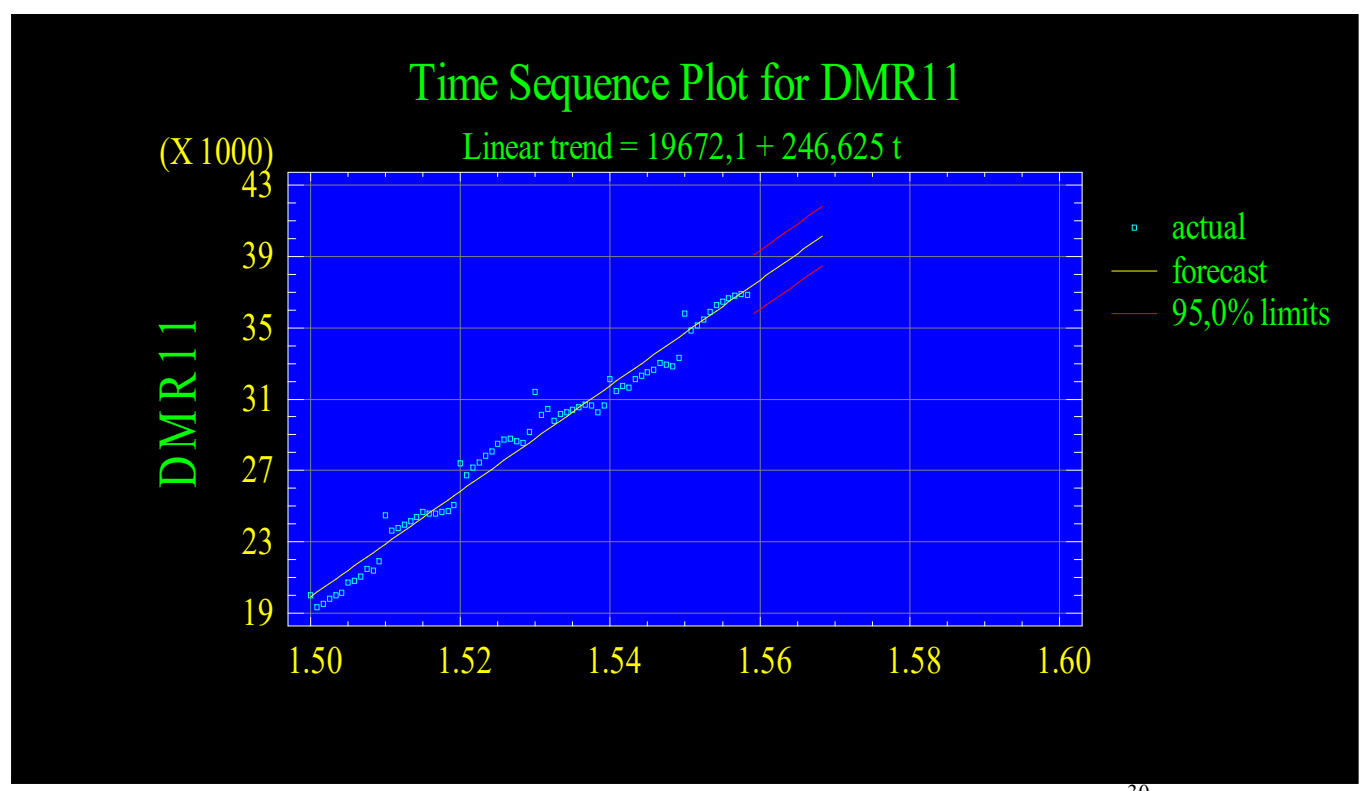

Figure 5: The dynamics of monetary stock of Russia ${ }^{30}$.

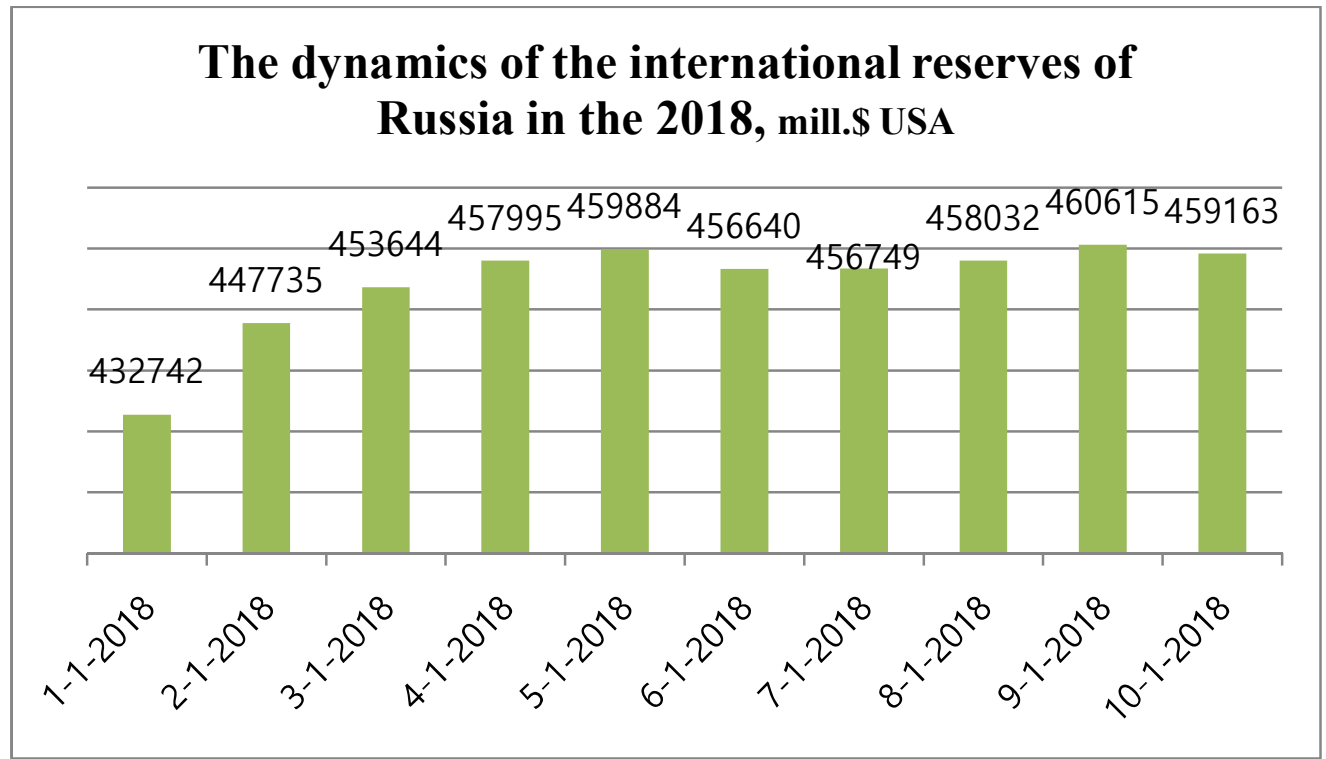

Figure 6: The dynamics of the international reserves of Russia in the 2018.

\footnotetext{
${ }^{30}$ The data array was investigated with the 1993 to 01.09 .2018 .
} 


\section{The dynamics of the international reserves of} Russia in the 2014-2018, mill.\$ USA

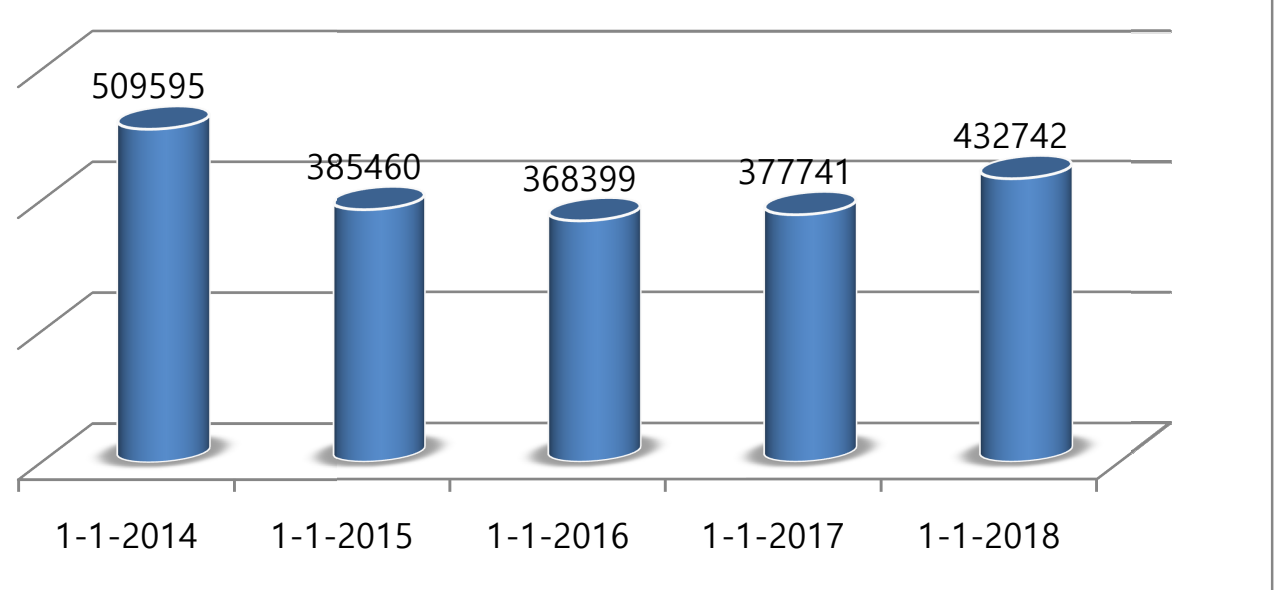

Figure 7: The dynamics of the international reserves of Russia in the 2014-2018.

\section{The structure of international reserves of Russia on the 01.09.2018}

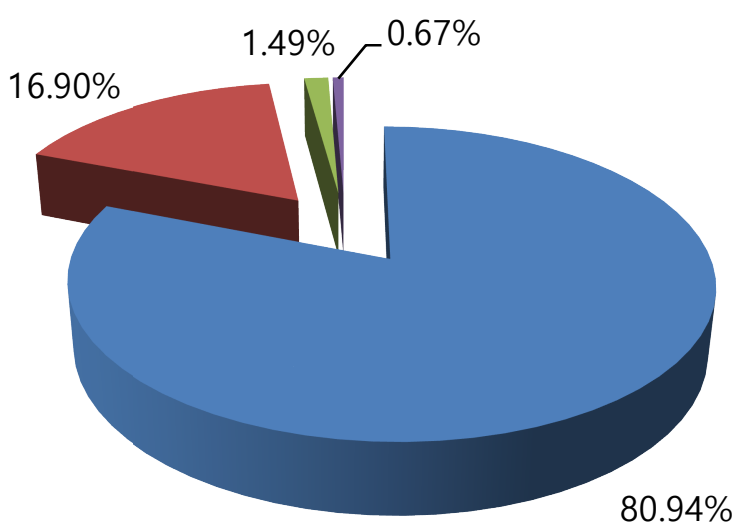

Number 1 - the currency assets, Number 2 - the monetary gold, Number 3 - SDR, Number 4 - the reserve position at the IMF.

Figure 8: The structure of international reserves of Russia in the 2018. 


\section{The dynamics of GDP of Russia in the 2017- 2018, billion RUB}

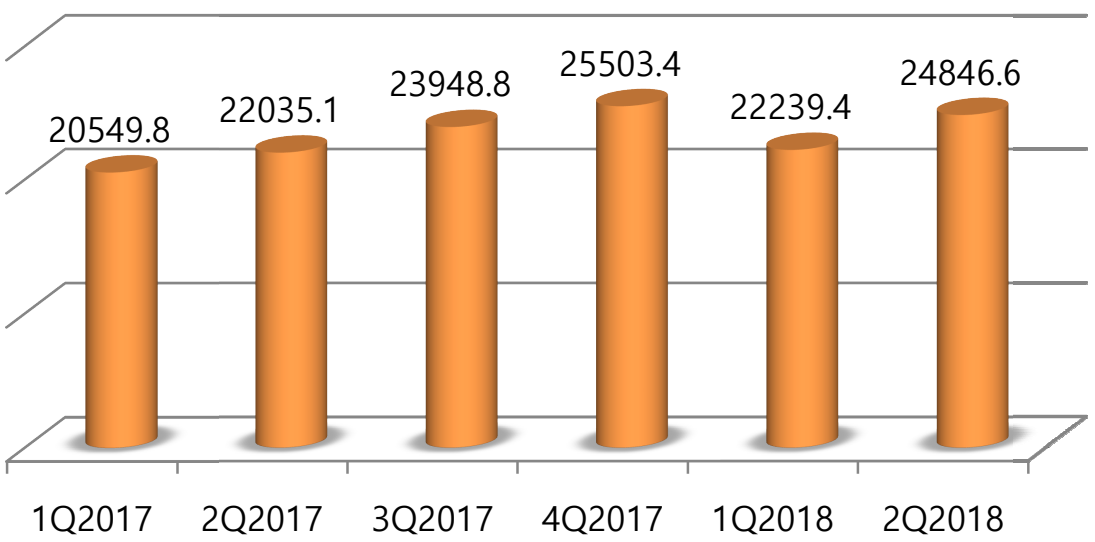

Figure 9: The dynamics of GDP of Russia in the 2017-2018.

\section{The dynamics of external debt of Russia in the 2017-2018, mill.\$ USA}

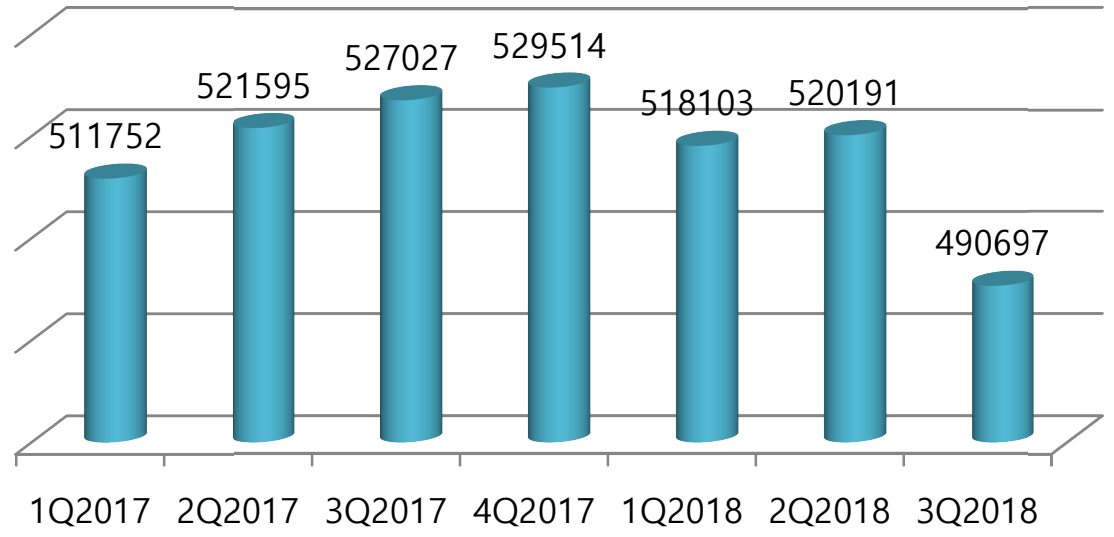

Figure 10: The dynamics of external debt of Russia in the 2017-2018. 


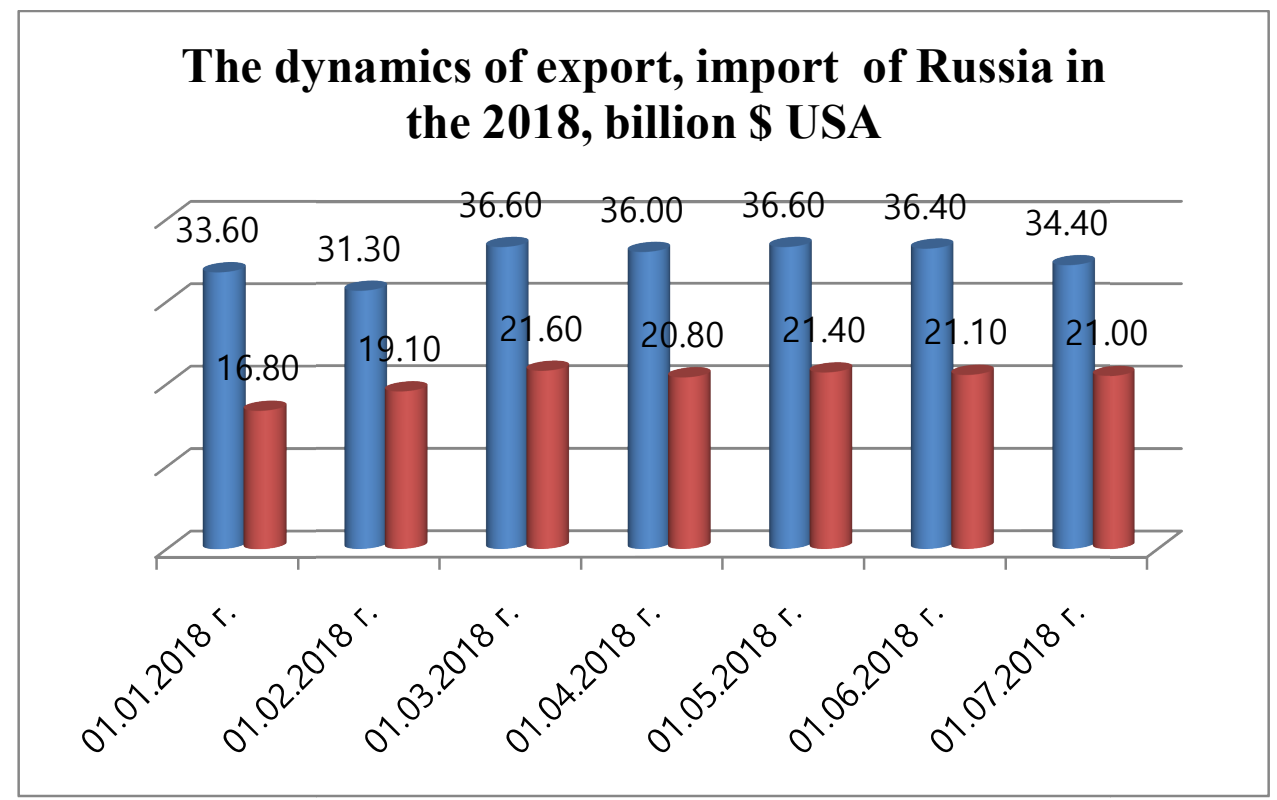

Row 1 - the export, Row 2 - the import.

Figure 11: The dynamics of export, import of Russia in the 2018.

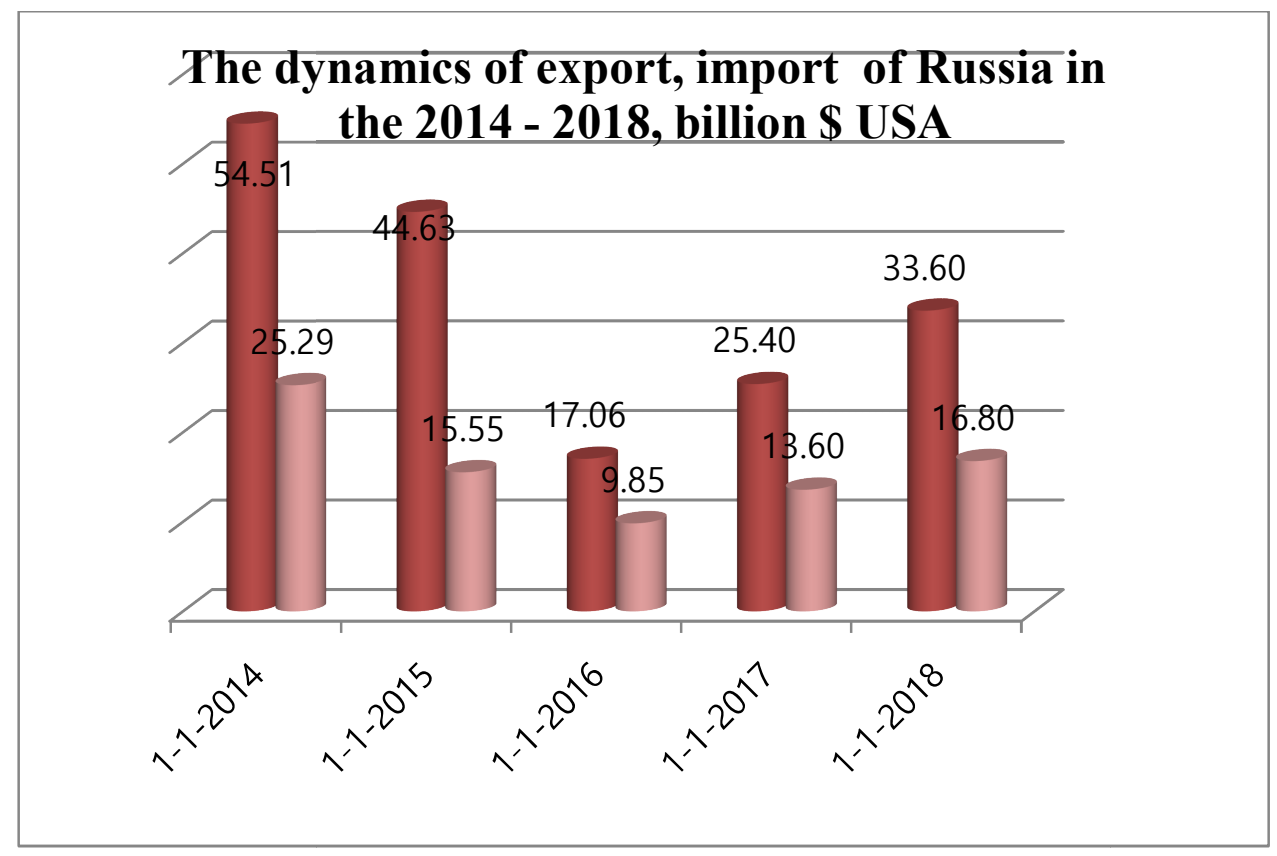

Row 1- the export, Row 2 - the import.

Figure 12: The dynamics of export, import of Russia in the 2014 - 2018. 
Appendix B

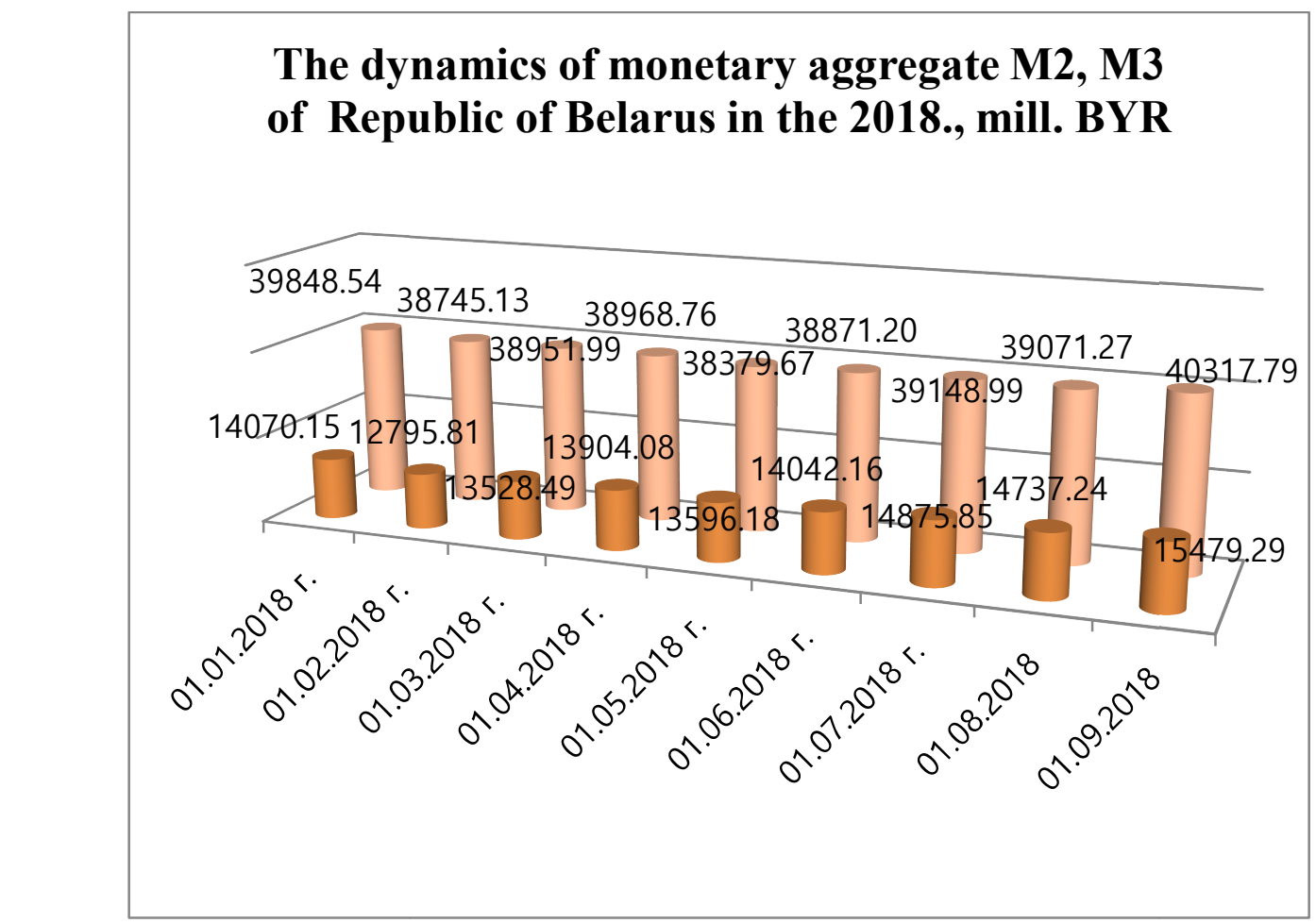

Row 1 - the monetary aggregate $\mathrm{M} 2$,

Row 2 - the monetary aggregate M3 (monetary stock).

Figure 1: The dynamics of monetary aggregate of Republic of Belarus in the 2018 .

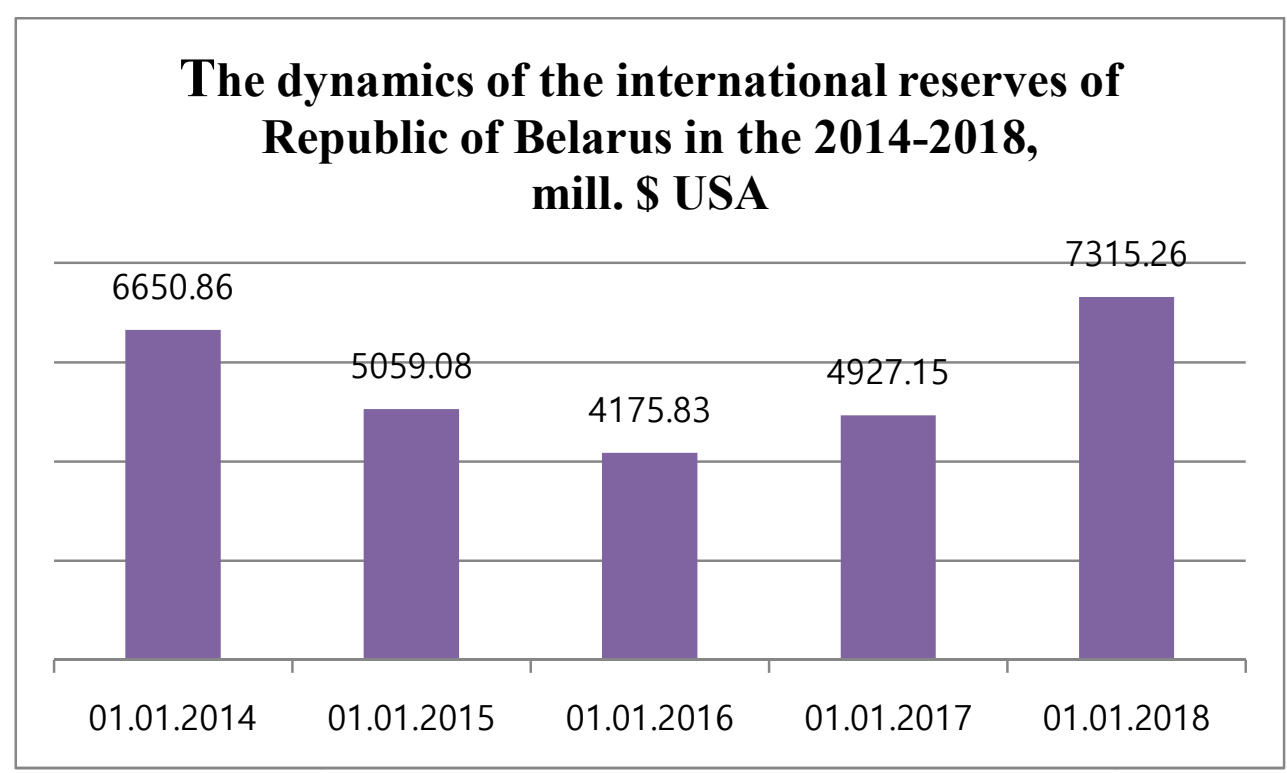

Figure 2: The dynamics of the international reserves of Republic of Belarus in the 2014-2018. 


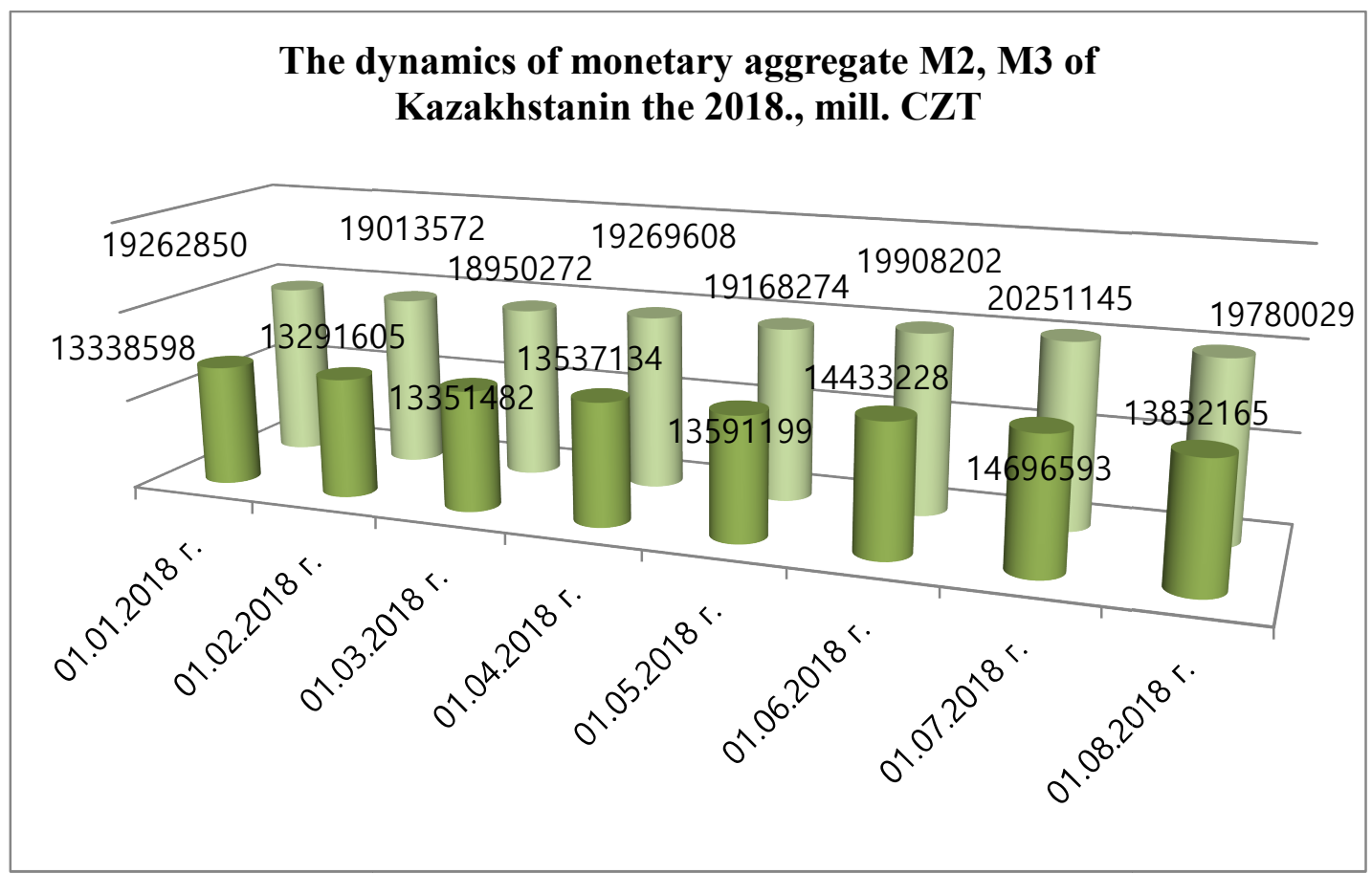

Row 1 - the monetary aggregate M2,

Row 2 - the monetary aggregate M3 (monetary stock).

Figure 3: The dynamics of monetary aggregate of Kazakhstan in the 2018.

Appendix C

\section{The dynamics of monetary stock of Japan in the 2018, billion JPY}
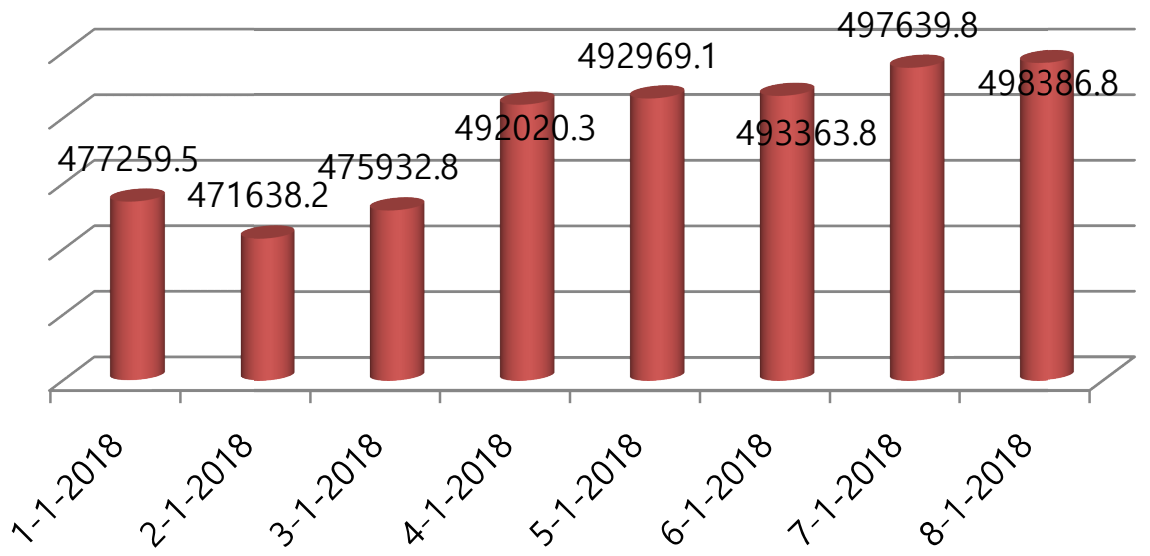

Figure 1: The dynamics of monetary stock of Japan in the 2018. 


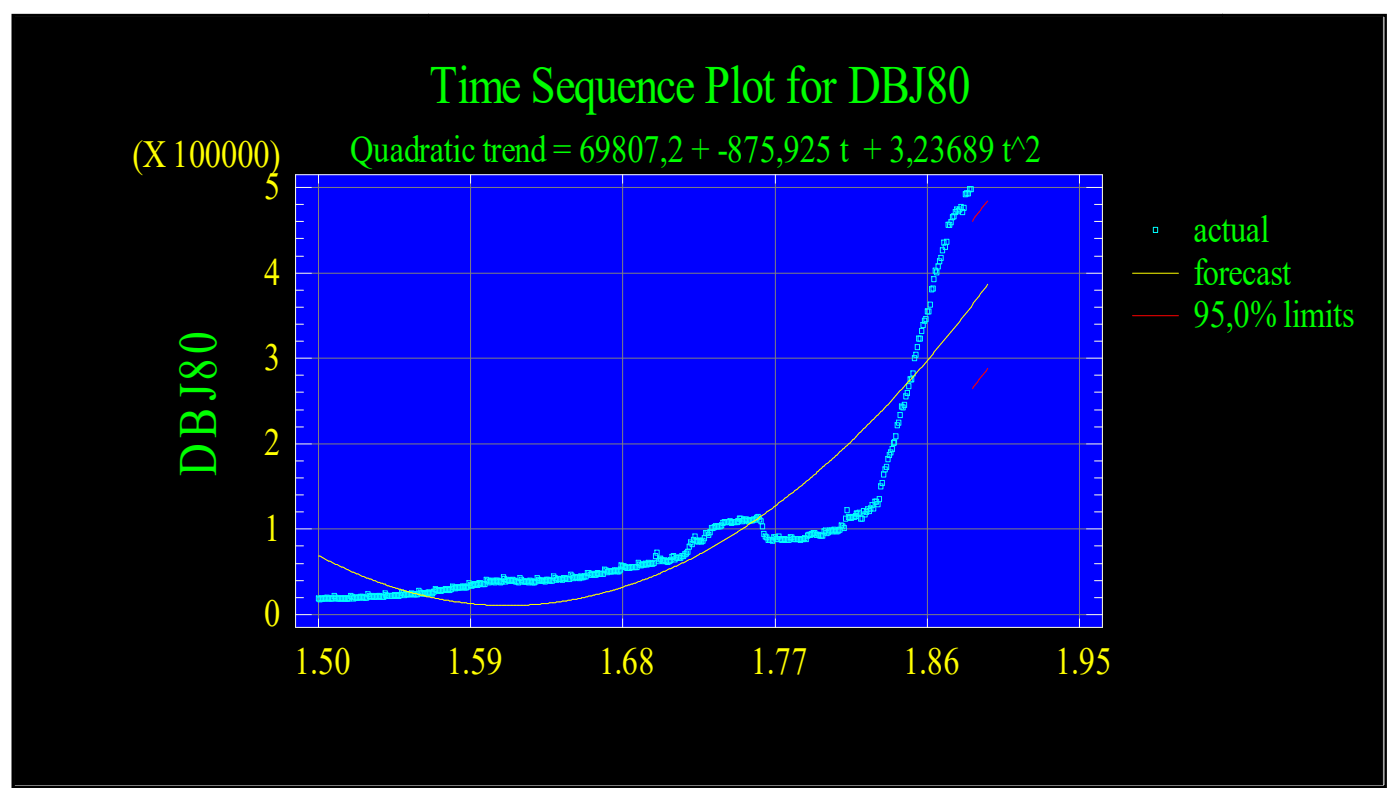

Figure 2: The dynamics of monetary stock of Japan ${ }^{31}$.

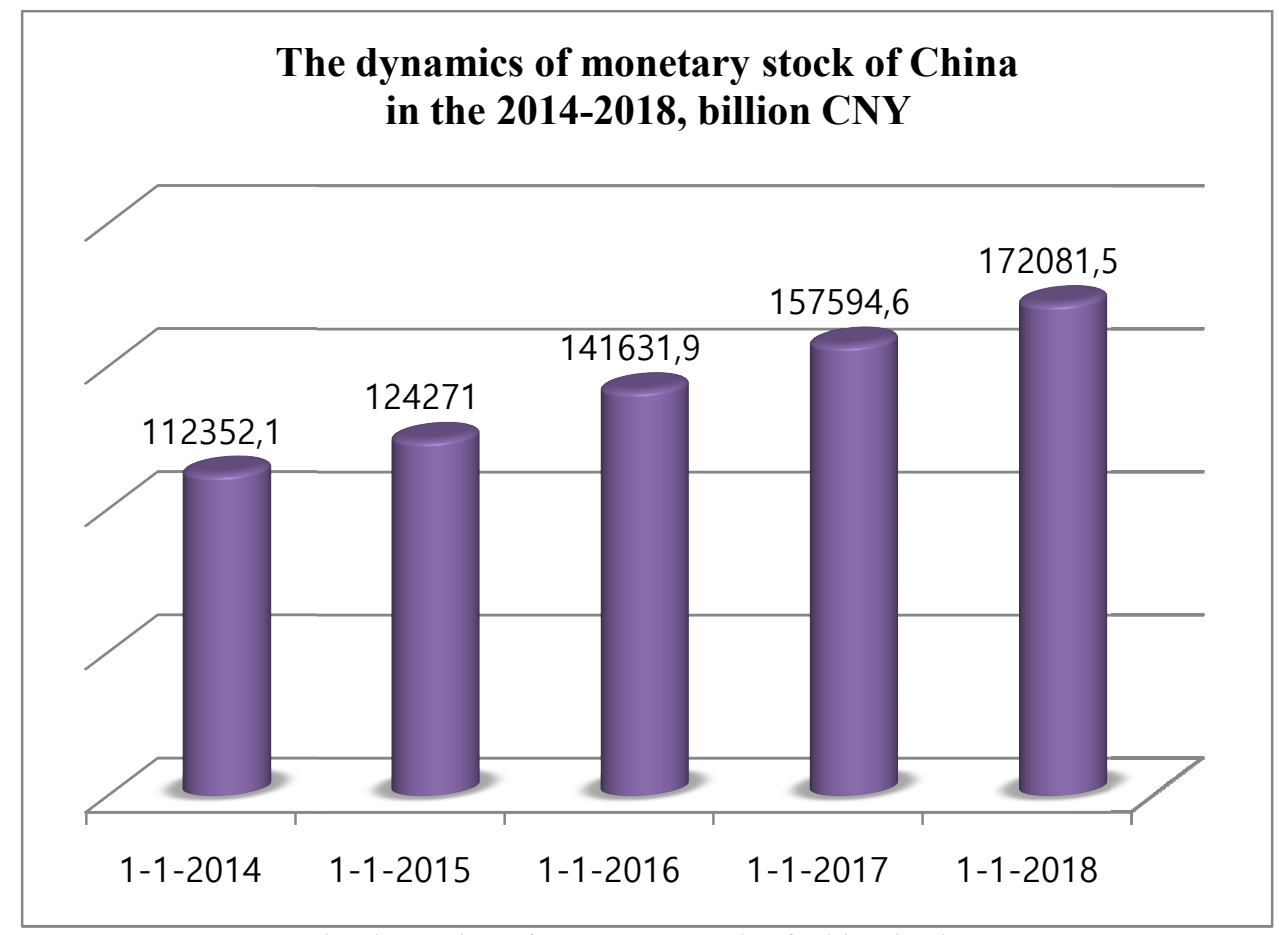

Figure 3: The dynamics of monetary stock of China in the 2014-2018.

\footnotetext{
${ }^{31}$ The data array was investigated with the 1980 to 01.08 .2018 .
} 


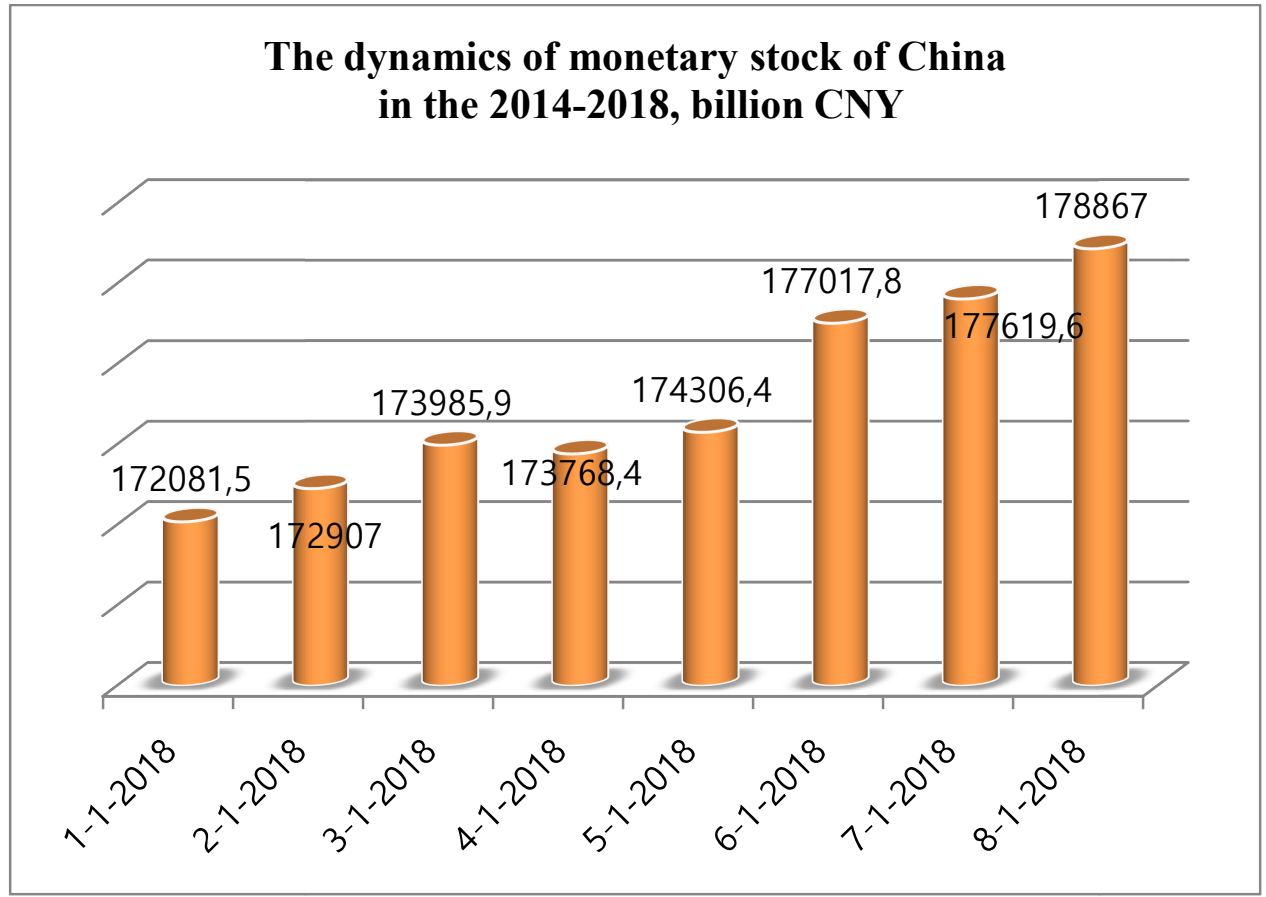

Figure 4: The dynamics of monetary stock of China in the 2018.

\section{The dynamics of the international reserves of China in the 2010-2017, mill. \$ USA}

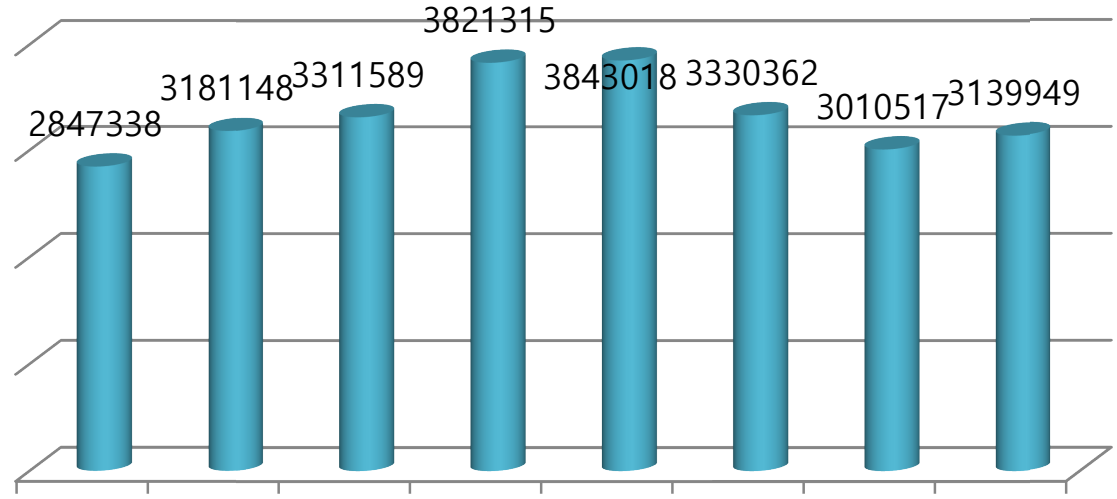

2010 г. 2011 г. 2012 г. 2013 г. 2014 г. 2015 г. 2016 г. 2017 г.

Figure 5: The dynamics of the international reserves of China in the 2010-2017. 


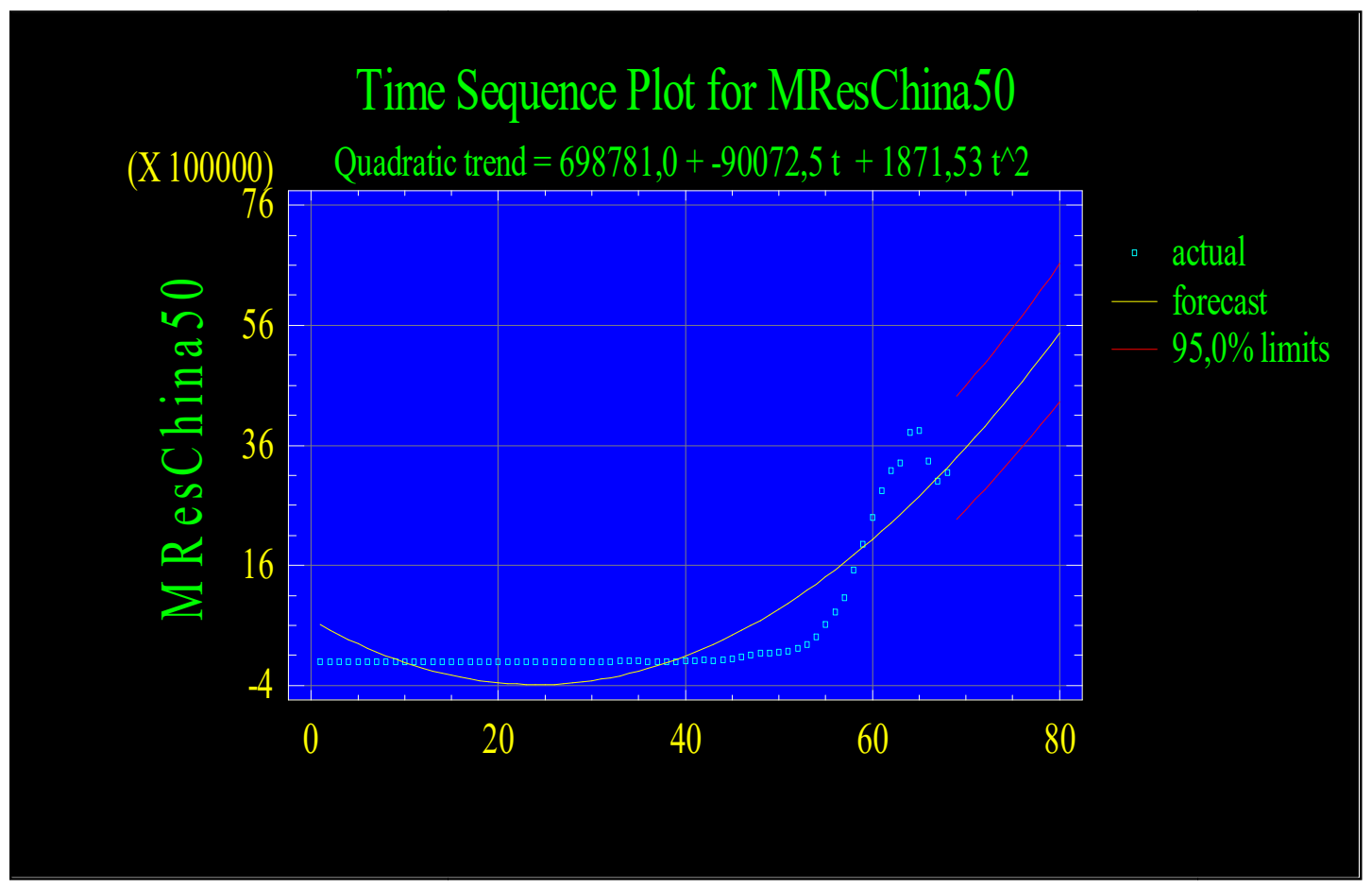

Figure 6: The dynamics of the international reserves of China ${ }^{32}$.

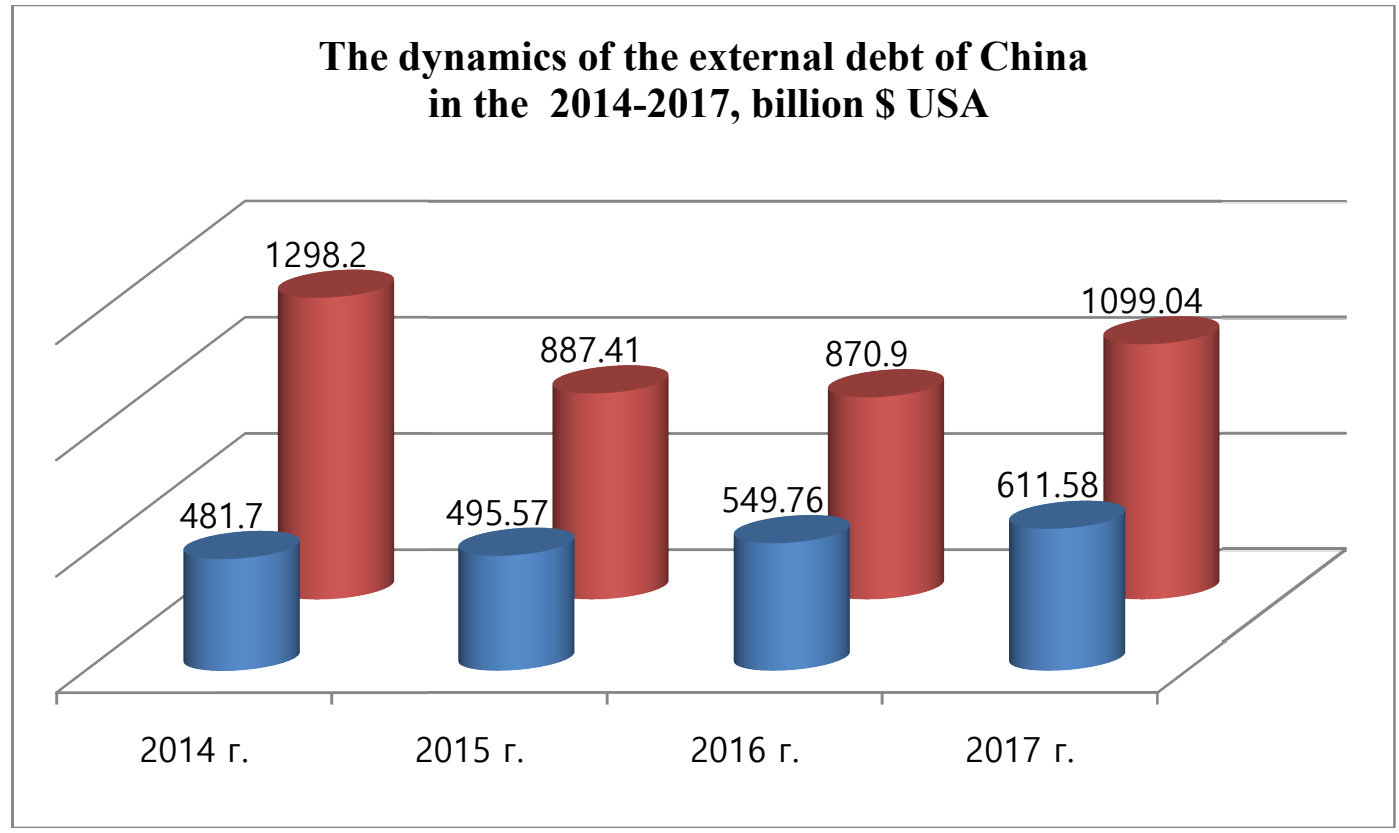

Figure7: The dynamics of the external debt of China in the 2014-2017.

\footnotetext{
${ }^{32}$ The data array was investigated with the 1950 to 01.08 .2017 .
} 


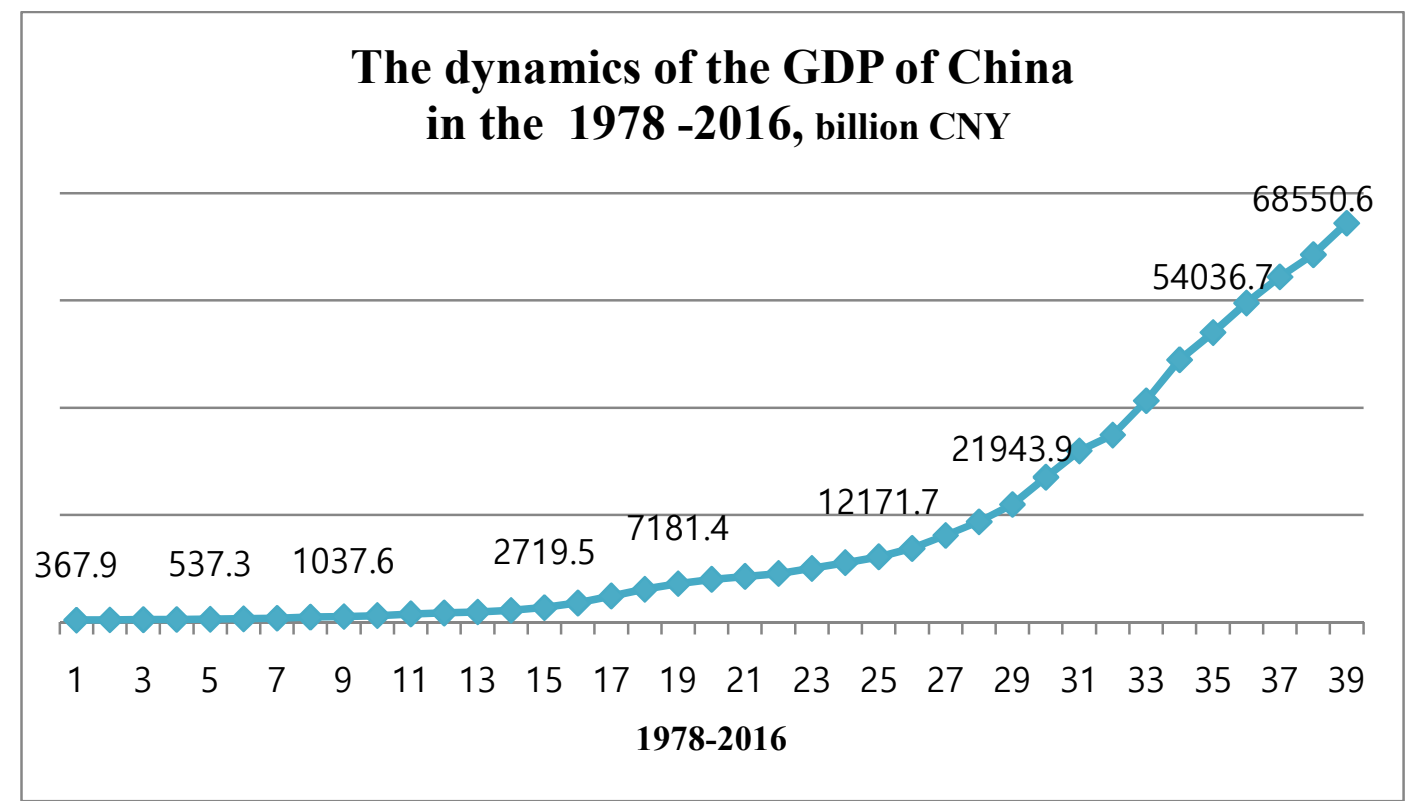

Figure 8: The dynamics of the GDP of China in the 1978-2016.

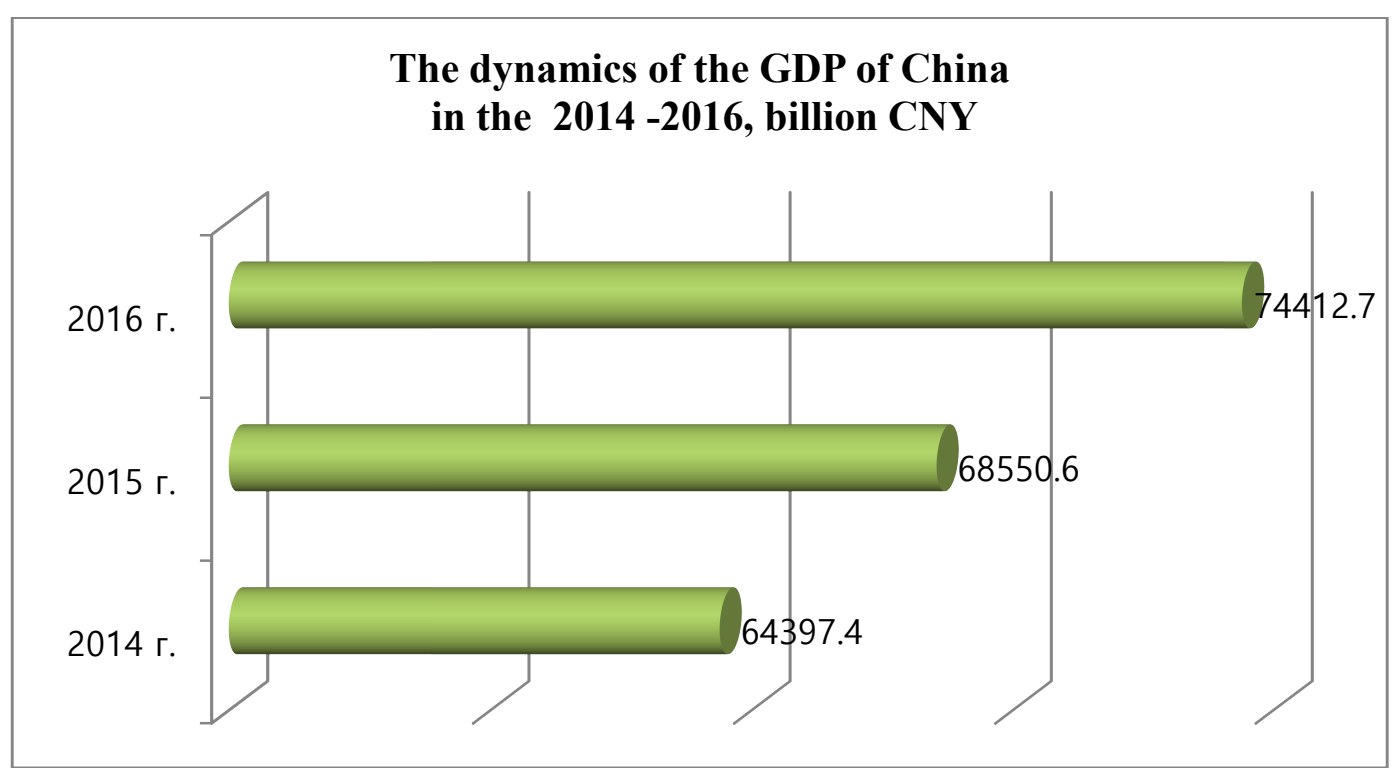

Figure 9: The dynamics of the GDP of China in the $2014-2016$. 


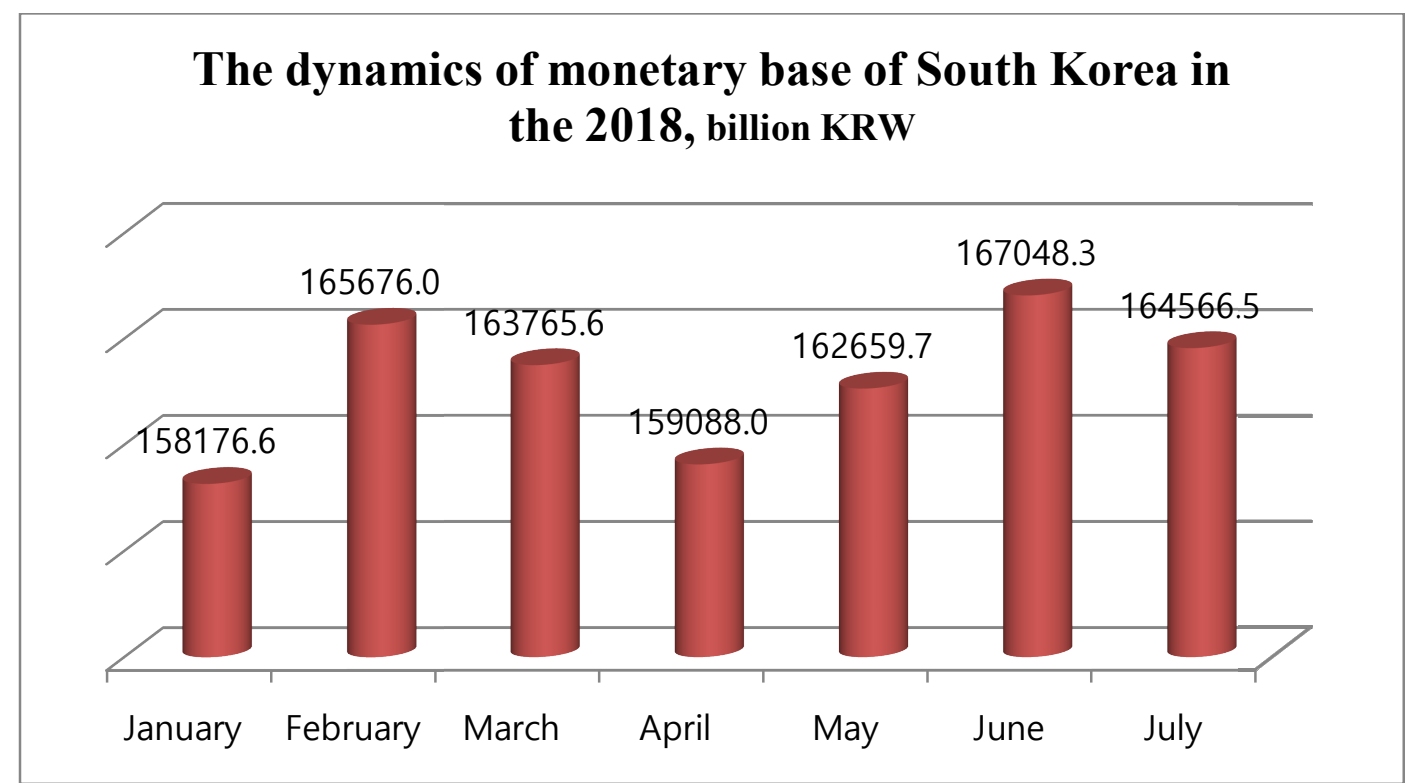

Figure 10: The dynamics of monetary base of South Korea in the 2018.

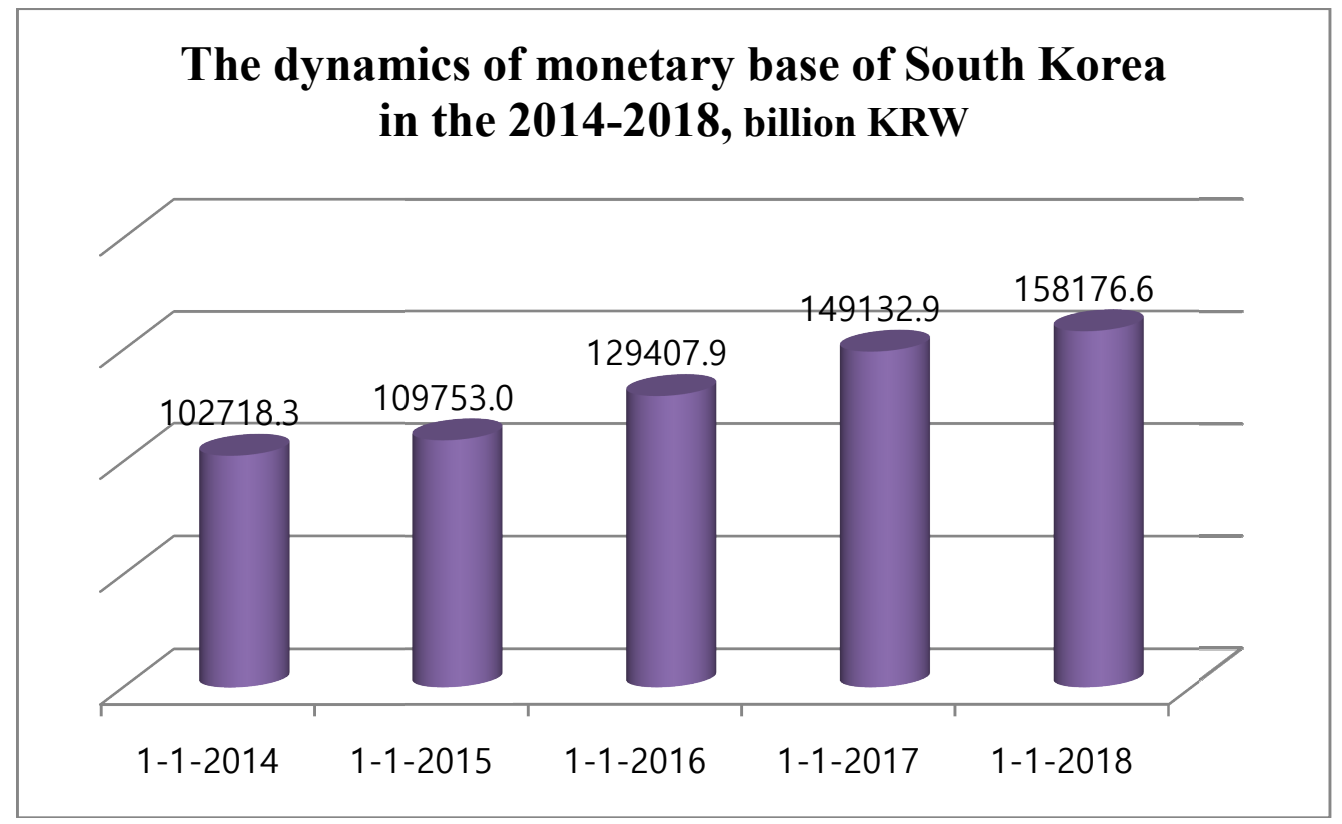

Figure 11: The dynamics of monetary base of South Korea in the 2014-2018. 


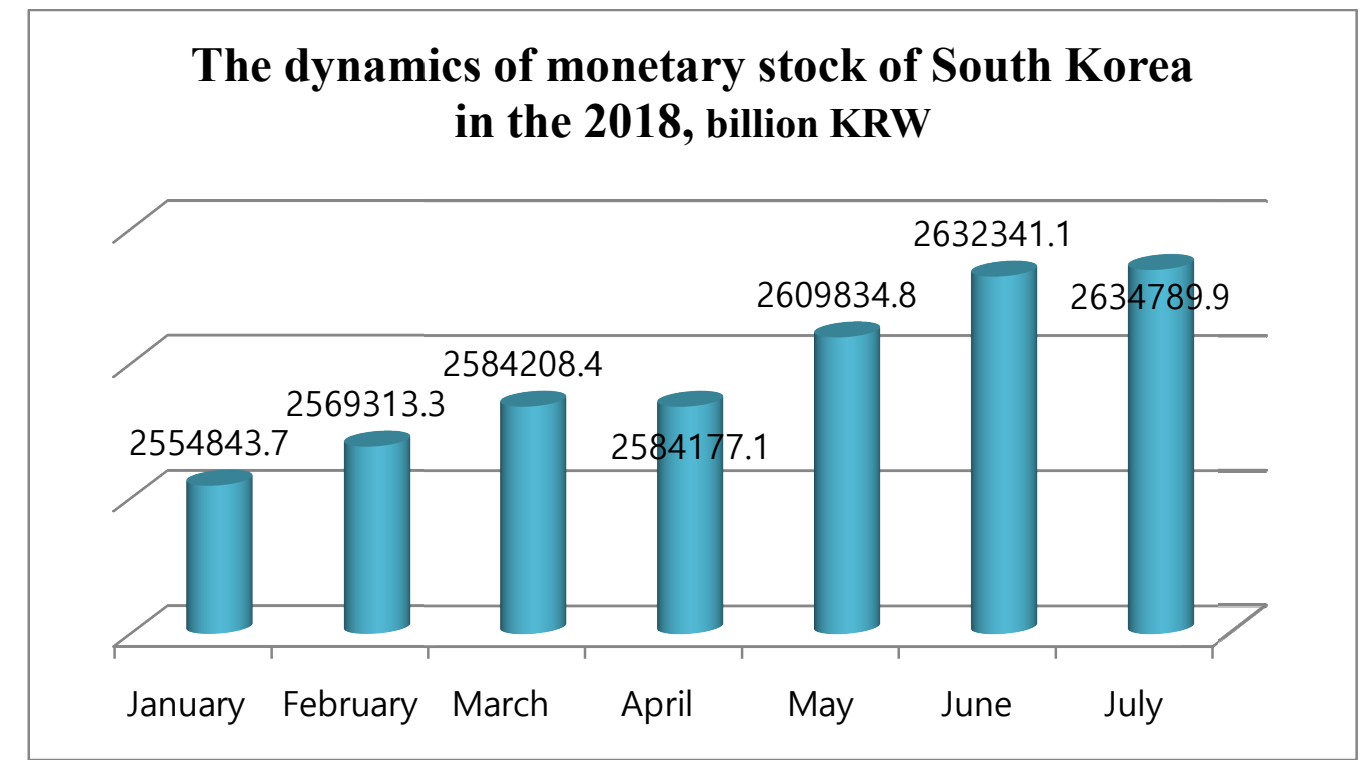

Figure 12: The dynamics of monetary stock of South Korea in the 2018.

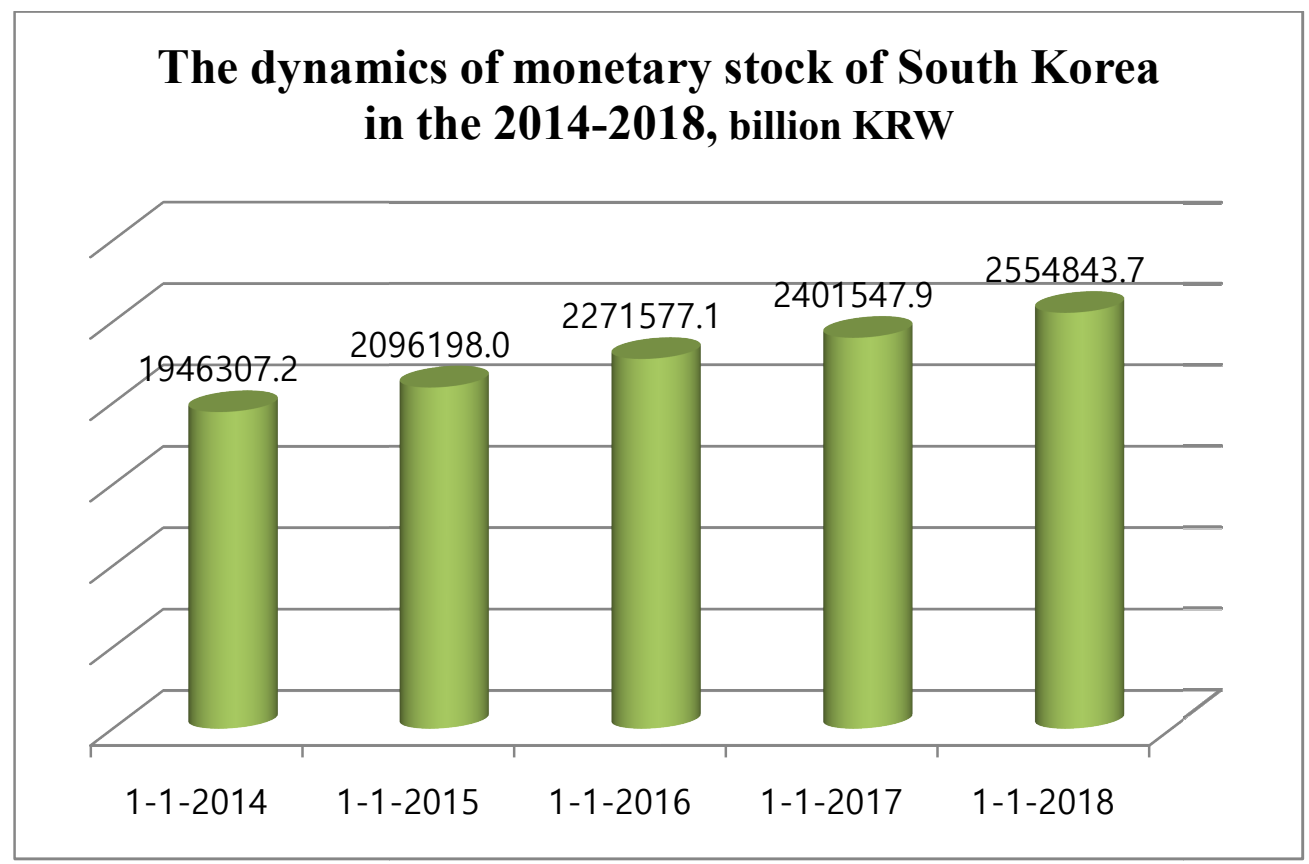

Figure 13: The dynamics of monetary stock of South Korea in the 2014-2018. 


\section{Time Sequence Plot for M1Kor70}

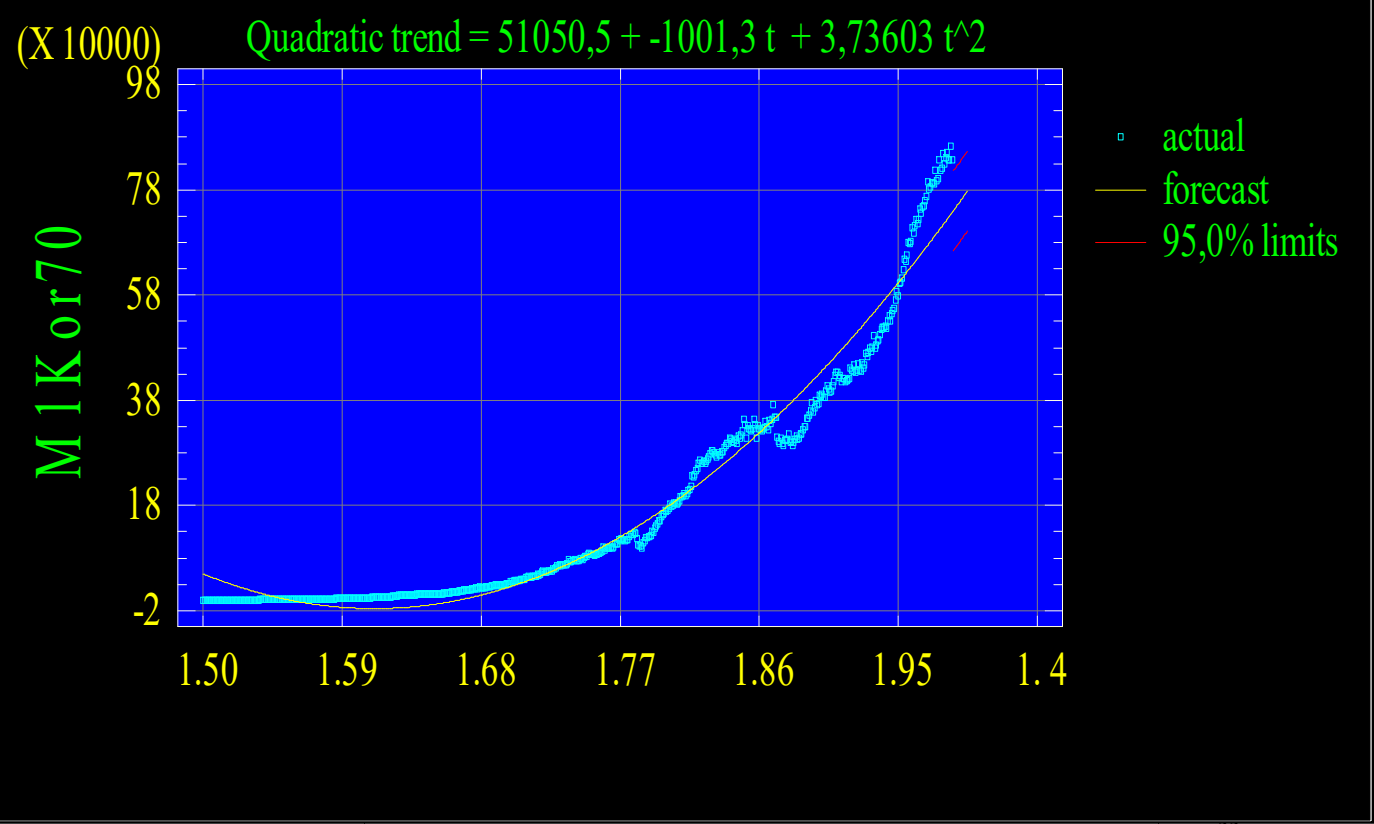

Figure 14: The dynamics of monetary aggregate M1 of South Korea in the 2014-2018 ${ }^{33}$.

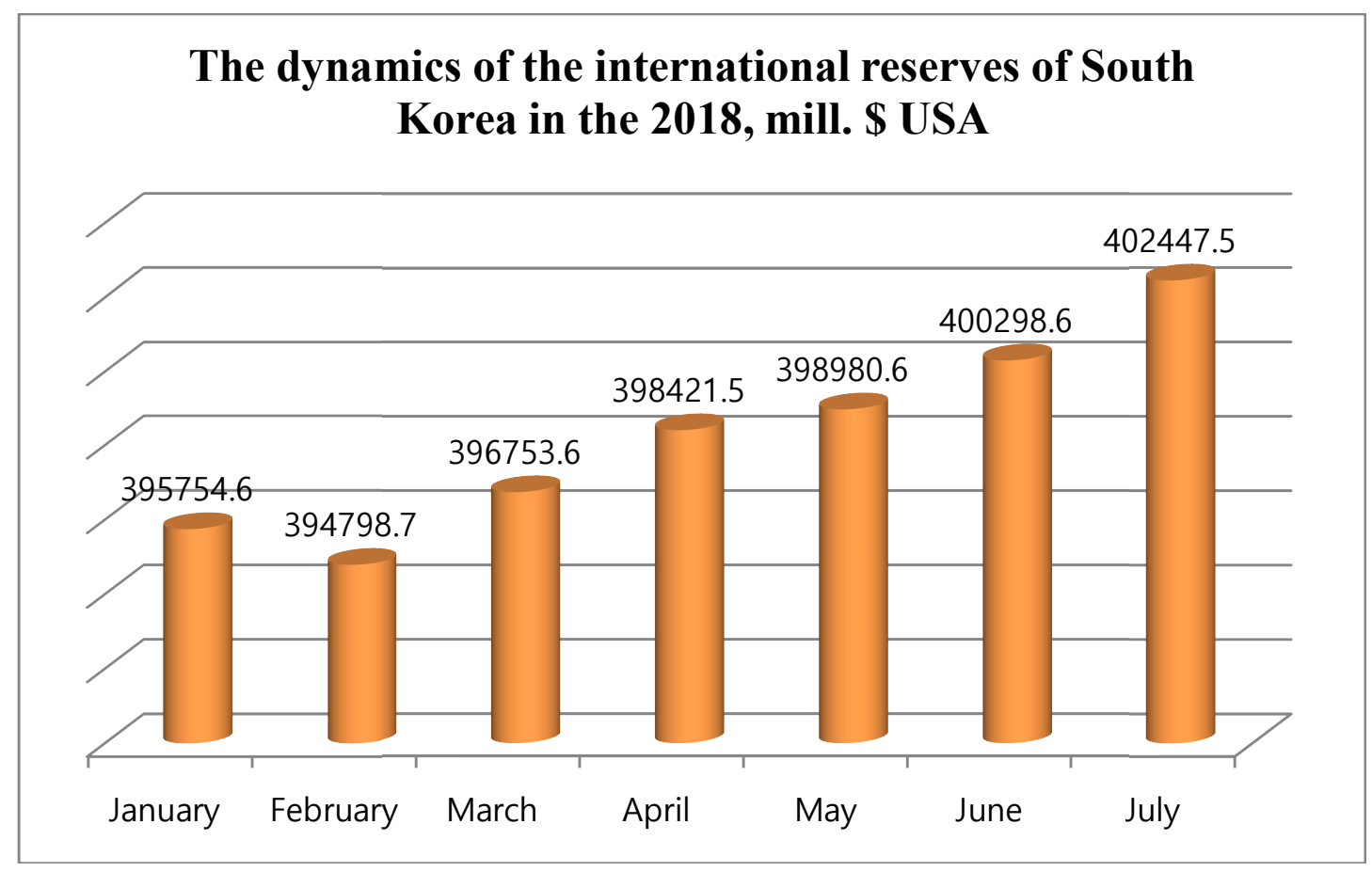

Figure 15: The dynamics of the international reserves of South Korea in the 2018.

\footnotetext{
${ }^{33}$ The data array was investigated with the 1970 to 01.06 .2018 .
} 


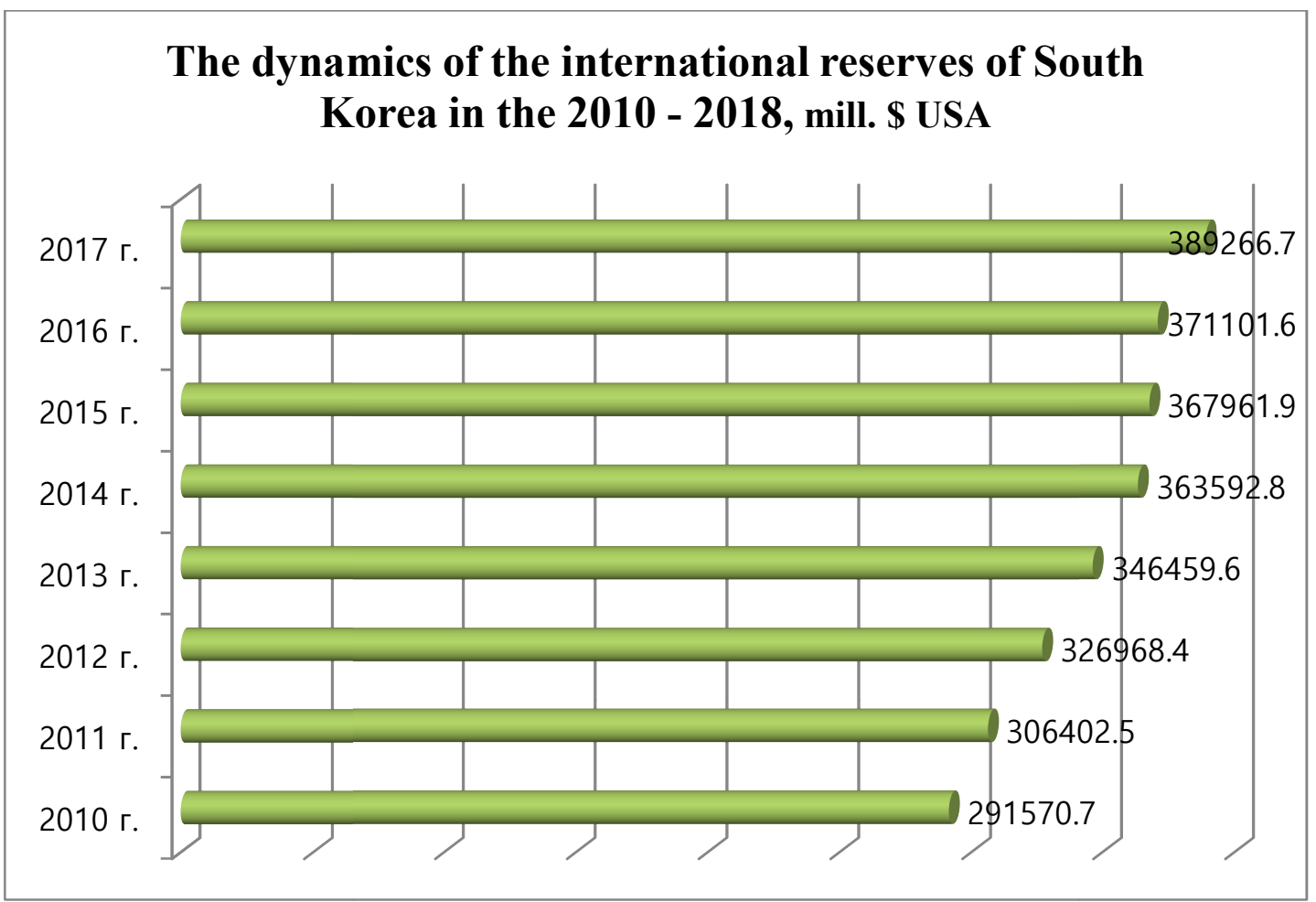

Figure 16: The dynamics of the international reserves of South Korea in the 2010 - 2018.

\section{The dynamics of GDP of South Korea in the 2010 - 2017, billion KRW}

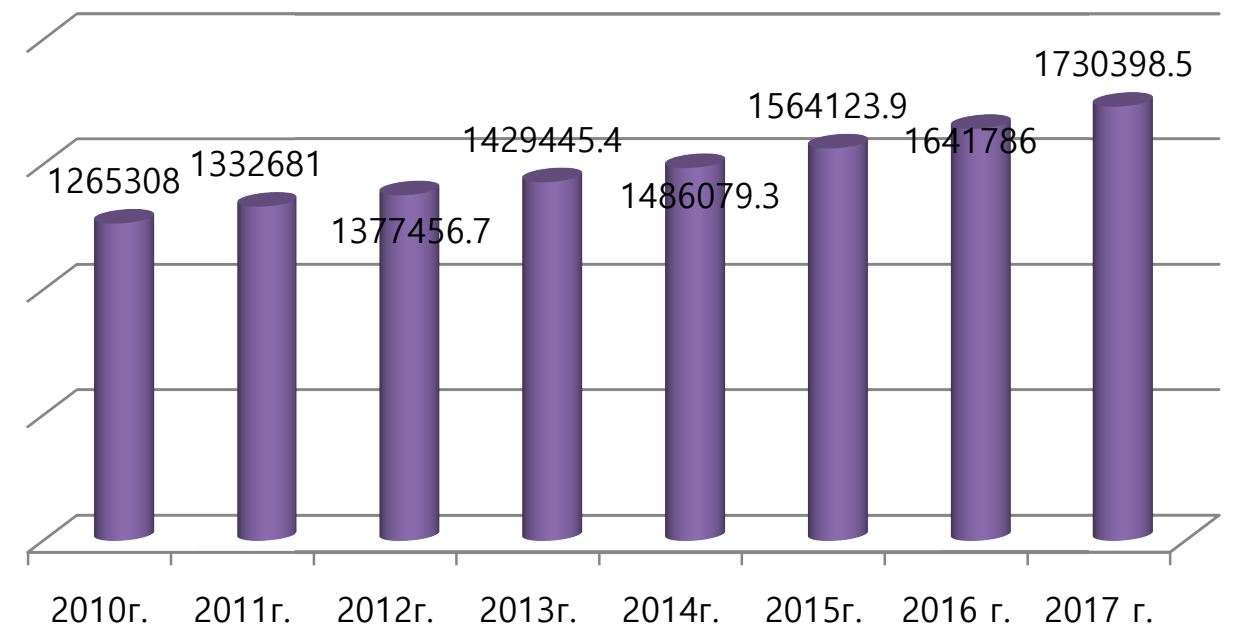

Figure 17: The dynamics of GDP of South Korea in the 2010 - 2017. 


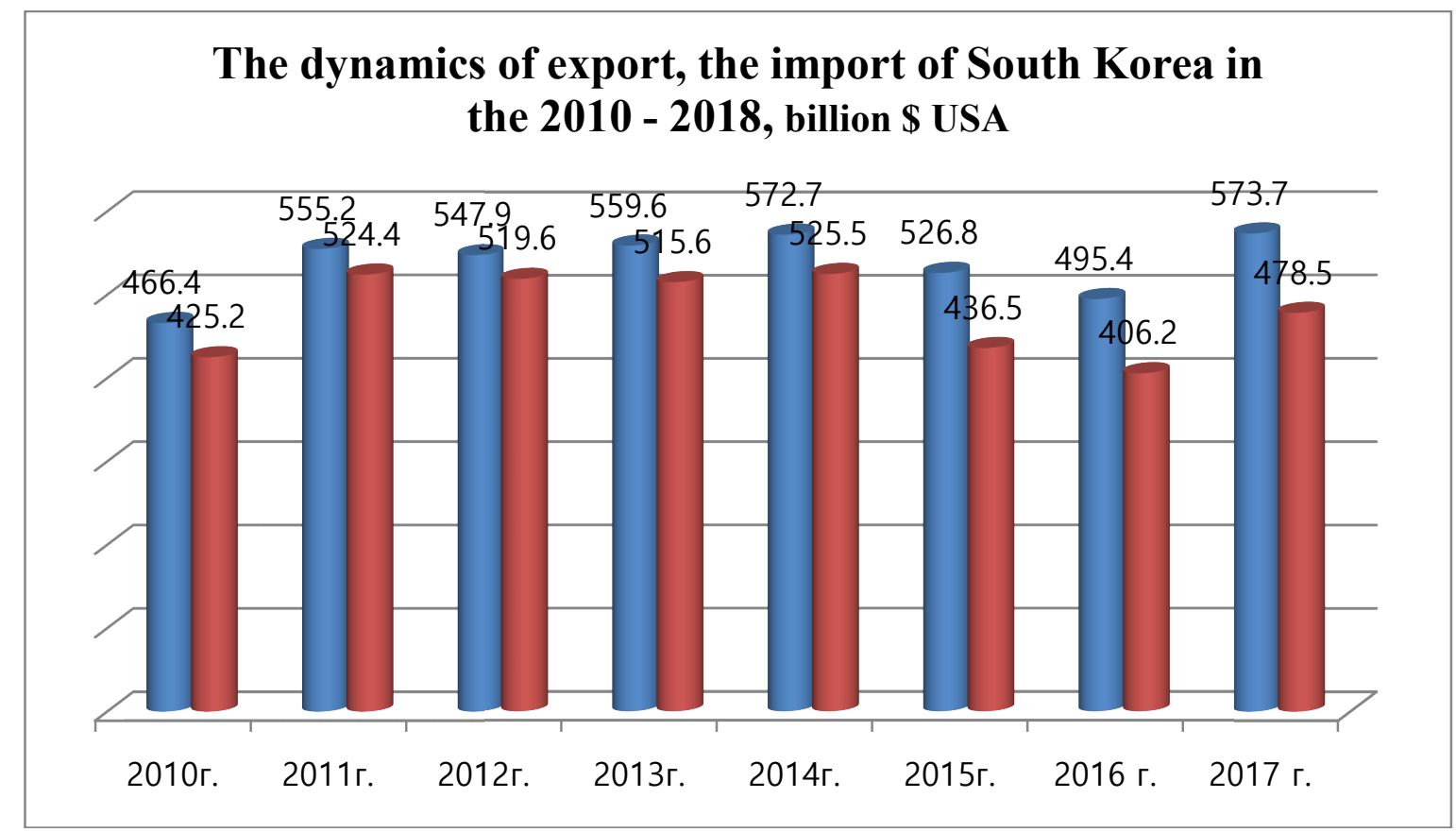

Row 1(blue) - the export, Row 2(red) - the import.

Figure 18: The dynamics of export, the import of South Korea in the $2010-2018$.

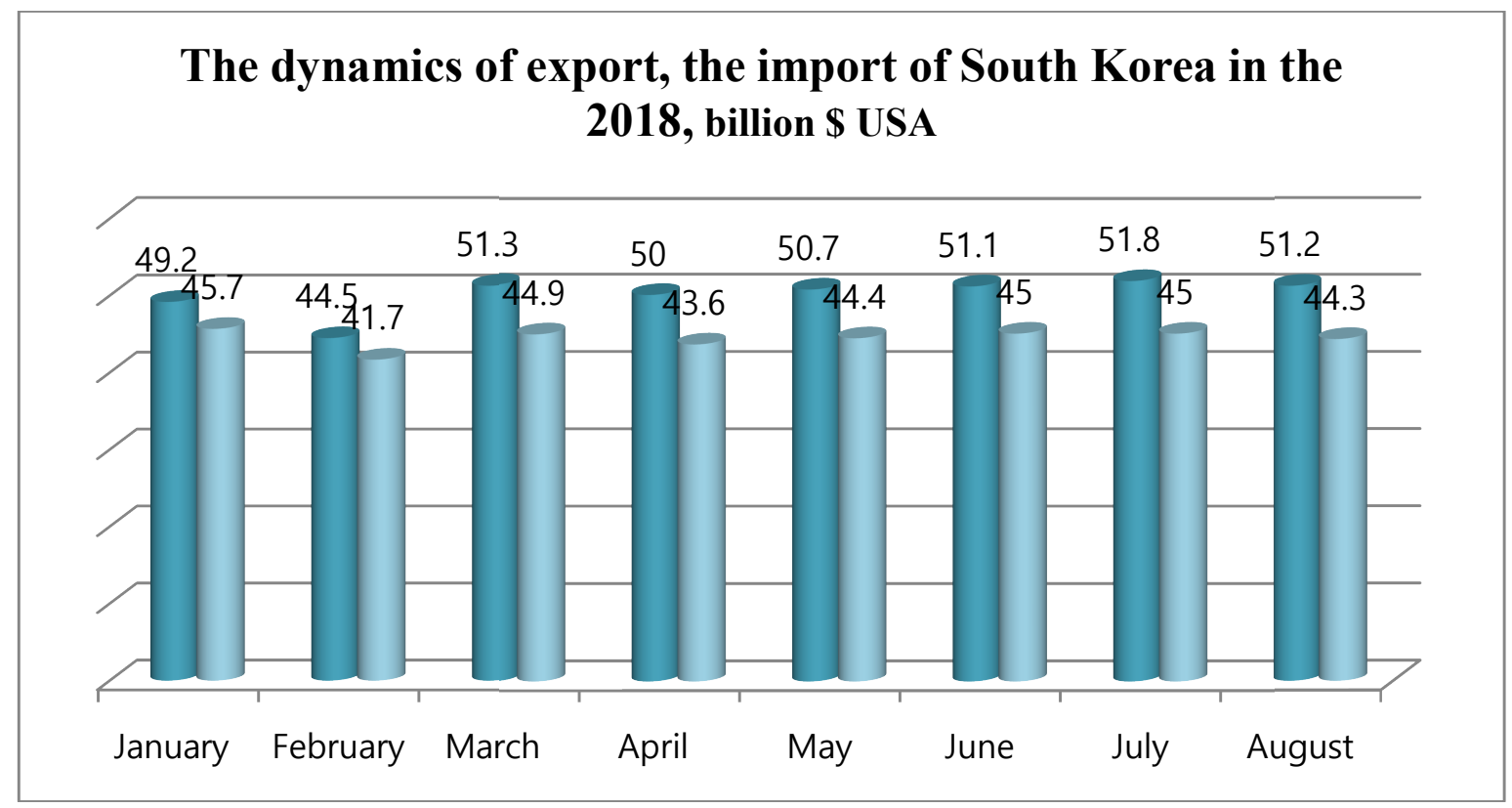

Row 1(left) - the export, Row 2(right) - the import.

Figure 19: The dynamics of export, the import of South Korea in the 2018. 


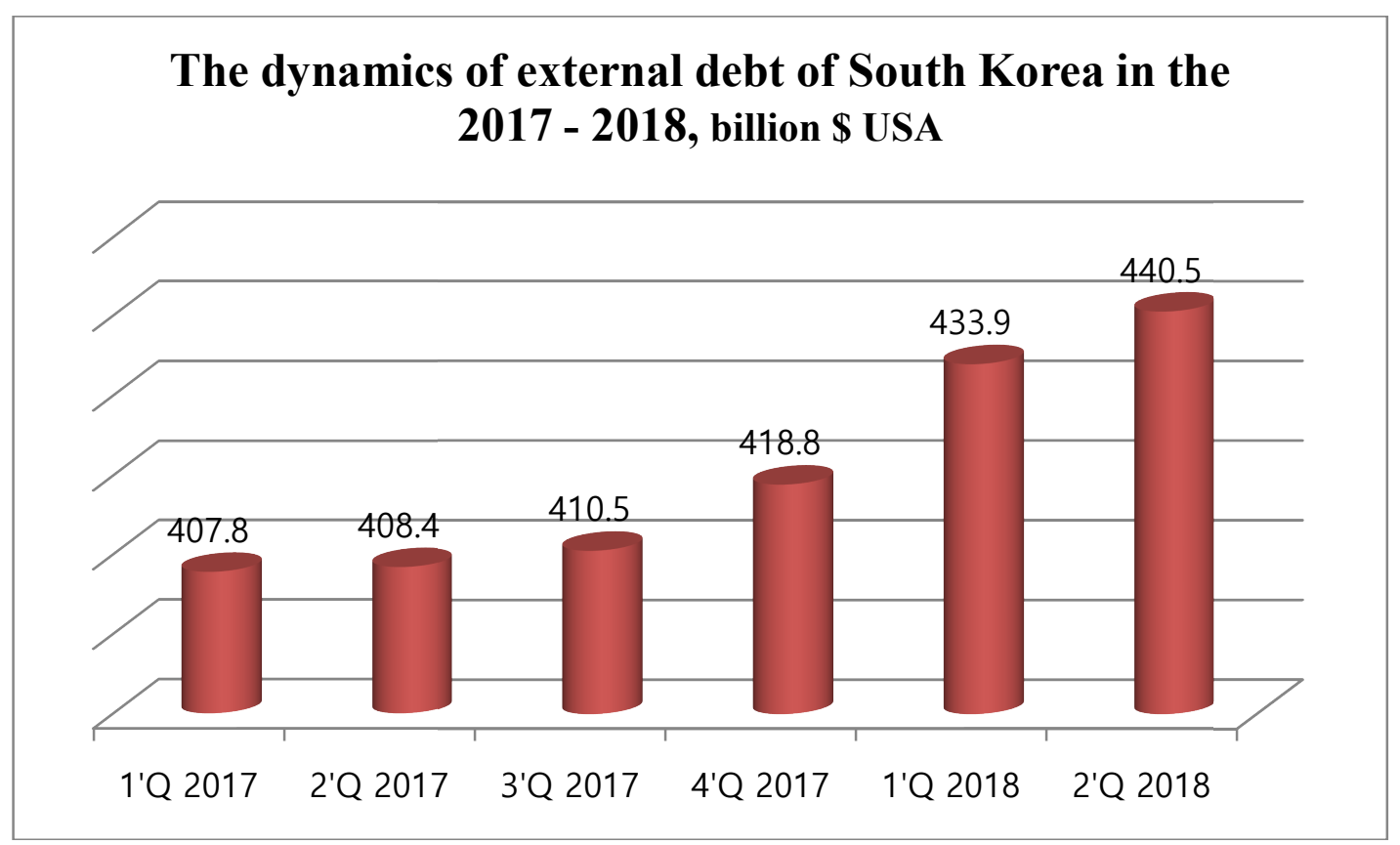

Figure 20: The dynamics of external debt of South Korea in the 2017 - 2018. 